Published in final edited form as:

Front Biosci (Landmark Ed). ; 20: 556-603.

\title{
Gene therapy for hemophilia
}

\author{
Geoffrey L. Rogers ${ }^{1}$ and Roland W. Herzog ${ }^{1}$ \\ ${ }^{1}$ University of Florida, Department of Pediatrics, Division of Cellular and Molecular Therapy, \\ Gainesville, FL 32610
}

\section{Abstract}

Hemophilia is an X-linked inherited bleeding disorder consisting of two classifications, hemophilia A and hemophilia B, depending on the underlying mutation. Although the disease is currently treatable with intravenous delivery of replacement recombinant clotting factor, this approach represents a significant cost both monetarily and in terms of quality of life. Gene therapy is an attractive alternative approach to the treatment of hemophilia that would ideally provide lifelong correction of clotting activity with a single injection. In this review, we will discuss the multitude of approaches that have been explored for the treatment of both hemophilia A and B, including both in vivo and ex vivo approaches with viral and nonviral delivery vectors.

\section{Keywords}

Gene therapy; Hemophilia; Factor IX; Factor VIII; AAV; Lentivirus; Review

\section{INTRODUCTION}

Hemophilia is an X-linked inherited disorder resulting in a deficiency in the clotting functionality of blood. Depending on which clotting factor the patient is deficient in, the disease is classified as hemophilia A (deficiency in factor VIII, F.VIII) or hemophilia B (deficiency in factor IX, F.IX). Hemophilia A has a higher prevalence, occurring in about 1:5,000 male births, while hemophilia B occurs in about 1:25,000. The loss of function of either F.VIII or F.IX results in a defect in the intrinsic clotting cascade (Figure 1). In the intrinsic pathway, exposure of circulating F.XII to a damaged surface causes its activation. Active F.XII (F.XIIa) activates F.XI, which then in conjunction with extrinsically activated tissue factor-F.VIIa complex (extrinsic factor Xase) proceeds to cleave the zymogens F.IX and F.X into their active forms, F.IXa and F.Xa. F.IXa is a serine protease whose function depends on the post-translational $\gamma$-carboxylation of F.IX by vitamin K. Meanwhile, activation by the extrinsic pathway also results in cleavage of the glycoprotein F.VIII into activated F.VIIIa. F.VIIIa (cofactor) and F.IXa (enzyme) come together to form the intrinsic factor Xase. This complex cleaves F.X into F.Xa at a rate much higher than the extrinsic factor Xase, such that in the end about 90 percent of F.Xa is produced by the intrinsic complex. The activity of the intrinsic factor Xase is dependent on binding to phospholipid 
membranes on endothelial cells or platelets as well as free $\mathrm{Ca}^{2+}$. Activated F.Xa facilitates the conversion of prothrombin into thrombin, which then catalyzes the formation of the fibrin clot. Thus, a genetic defect in F.VIII or F.IX prevents the assembly of the intrinsic factor Xase, significantly impairing the ability to activate F.X and induce formation of the fibrin clot.

While the determination of which factor is missing is important for treatment, the clinical symptoms of hemophilia A and B are essentially comparable. The severity of X-linked hemophilia is dependent on the degree of residual clotting activity. Mild cases $(5-40 \%$ activity) are typically asymptomatic outside of major trauma or surgery, whereas moderate cases (1-5\% activity) are somewhat more vulnerable, and may evidence prolonged bleeding even from minor injuries. However, severe hemophilia ( $<1 \%$ activity) brings additional complications. In addition to the difficulty responding to injury, these patients frequently develop spontaneous bleeds in capillary beds, particularly within joints. Over time, this causes significant chronic deterioration of the joints if not properly managed. Currently, hemophilia is treated by intravenous delivery of replacement clotting factor, either plasmaderived or recombinant. This therapy can be performed on demand, though it has been suggested that prophylactic management (typically 3 injections per week) can reduce joint damage over time (1). Longer-lasting clotting factors that would reduce the required frequency of injections are currently in development (2).

In addition to the inconvenience of these frequent injections, protein replacement therapy also carries the risk of deleterious immune responses against the therapeutic protein. As patients are not naturally producing clotting factor, the immune system can recognize the exogenous protein as a foreign antigen and form antibodies against the protein that prevent its function; these neutralizing antibodies are also known as inhibitors. The frequency of inhibitor formation varies by disease: about $25-30 \%$ of hemophilia A, but only about $5 \%$ of hemophilia B patients develop inhibitors. The risk for inhibitor formation varies depending on a number of factors, including the severity of the underlying mutation; both preclinical and clinical studies indicate that more residual protein expression reduces inhibitor formation in both hemophilia A and B (3-7). Although the frequency of inhibitors in hemophilia B is reduced, they are typically more severe, with the potential for anaphylaxis as well as nephrotic syndrome due to circulating antigen-antibody complexes (5). Currently, the only treatments for inhibitor formation are immune tolerance induction (ITI) protocols. These procedures are both costly and time-consuming, and during the procedure bypass reagents must be employed which are both less effective and more risky. Additionally, the treatment is typically effective in only around two-thirds of patients $(8,9)$.

Gene therapy represents an appealing alternative to protein replacement therapy. Instead of repeated injections of protein, it would ideally involve a single injection that would induce long-term production of the defective clotting factor. Expression at only $5 \%$ of endogenous levels can improve the disease to a mild phenotype and essentially eliminate the risk of spontaneous bleeding events as well as the need for prophylactic protein therapy. Although a variety of mechanisms to introduce the transgene have been investigated, some of the most popular are recombinant viral vectors. In particular, adeno-associated virus (AAV), a small and non-pathogenic parvovirus with an episomal genome, has been used extensively, 
including in multiple clinical trials for the treatment of hemophilia B (10). Additionally, lentiviral vectors (LV) based on HIV-1 which integrate into the host's genome have also been employed in a multitude of preclinical studies both for in vivo and ex vivo gene transfer (11). Finally, in addition to these gutted viral vectors, research is also being performed on non-viral gene transfer (12). Some examples of sustained correction via liver-directed AAVmediated gene transfer are demonstrated in figure 2. These include correction of whole blood clotting time in canine studies and activated partial thromboplastin time (aPTT) in mice for hemophilia B, as well as aPTT correction in a murine model of hemophilia A (Figure 2A, C).

However, beyond merely introducing the transgene, it is also important to maintain production of the clotting factor by avoiding the deleterious impact of the immune system on gene transfer, either against the delivery vector or the transgene itself. For instance, preclinical studies with $L V$ vectors have revealed that innate immune responses involving type I interferon (IFN) production can lead to impaired transgene expression and $\mathrm{CD} 8^{+} \mathrm{T}$ cell responses against the transgene $(13,14)$. Clinical trials of AAV-mediated gene transfer have also revealed the detrimental impact of pre-existing immunity to the AAV capsid, both in regards to neutralizing antibodies (NAB) preventing transduction as well as a memory $\mathrm{CD}^{+} \mathrm{T}$ cell response to the viral capsid that can eliminate transduced hepatocytes (15). Finally, there is always the risk of an immune response against the clotting factor itself (particularly in the case of hemophilia A), which would inhibit the gene therapy itself as well as obstructing further efforts to treat with recombinant protein (16). Beyond merely avoiding the immune response, though, it is preferable to actually induce immune tolerance to the transgenic protein, ensuring that endogenous production is not eliminated as well as allowing for the administration of supplemental clotting factor (e.g. during trauma or surgery) without provoking an inhibitor response $(16,17)$. Immune tolerance in preclinical studies is typically demonstrated by the intravenous administration of recombinant F.VIII or F.IX. This normally provokes an inhibitor response in hemophilic mice for both diseases; however, following gene transfer, mice that have been tolerized maintain clotting correction and fail to form inhibitory antibodies, as opposed to naïve control animals (Figure 2B, D). A variety of animal models of hemophilia are available for preclinical studies, and clinical trials for both diseases have been attempted as well (Figure 3). In this review, we will provide a comprehensive overview of viral and non-viral gene therapy approaches for both hemophilia B and hemophilia A, with an additional focus on the ability of these approaches to avoid destructive immunity or induce transgene-specific tolerance.

\section{GENE THERAPIES FOR HEMOPHLIA B}

Of the two diseases, gene therapy for hemophilia B has been more successful, having advanced to multiple recent clinical trials. Primarily, this is due to the simplicity of F.IX compared to F.VIII. The $F 9$ coding region is only about $1.4 \mathrm{~kb}$, and it encodes a single domain protein of 461 amino acids. This small size allows it to be easily packaged in a recombinant adeno-associated virus, a gene therapy vector that has provided promising results for a variety of genetic disorders (18). Additionally, the posttranslational modification of F.IX can be effectively carried out in skeletal muscle, allowing early studies 
to be carried out in a target tissue less risky than a critical organ such as the liver, the natural site of F.IX synthesis (19).

\subsection{Adeno-associated virus}

Adeno-associated virus (AAV) is a parvovirus with a single-stranded DNA genome of about $4.7 \mathrm{~kb}$. It is a dependovirus that is unable to replicate in the absence of a helper virus such as adenovirus; thus, although it is a common natural infection, AAV is not associated with any known pathogenic infections in humans. Recombinant AAVs are modified by the removal of any DNA encoding for viral protein. Only the inverted terminal repeats (ITRs) required for packaging are retained from the viral genome, giving rAAV vectors a packaging capacity of about $5 \mathrm{~kb}$ for the promoter and gene of interest. Several factors make AAV an attractive vector for in vivo gene therapy, including its ability to infect non-dividing cells, the maintenance of vector genomes as episomal concatemers (minimizing the risk of insertional mutagenesis), its low immunogenicity, and the wide variety of capsid serotypes that allow gene delivery to numerous target tissues (20-24).

Early studies for gene therapy for hemophilia B with AAV focused on delivery to skeletal muscle, both in animal models (mice and dogs) and humans (25-30). Although more recent clinical trials for gene transfer to skeletal muscle have used AAV serotype 1 (AAV1) vectors due to their superior transduction capacity in myocytes, these early studies used AAV2 vectors (29-34). It was found that expression of functional human factor IX (hF.IX) was possible in skeletal muscle, though potential complications from an immune response against hF.IX could occur in some situations, particularly in cases with more severe mutations $(3,27,35)$. The local F.IX expression and anti-F.IX immune response were found to be critically important during muscle-directed gene transfer, and this consequence could be avoided by carefully titering the vector dose per site or with transient immunosuppression (35-39). In a clinical trial, intramuscular delivery of hF.IX to patients with missense mutations met safety requirements and demonstrated that in vivo gene therapy with AAV could be a viable treatment strategy; however, although the persistence of transduced fibers was observed for ten years, expression never reached therapeutic levels at any of the doses tested $(30,40)$. Although some preclinical studies are still studying intramuscular gene therapy, most research for hemophilia B-including clinical trials — has shifted to hepatic gene transfer $(41,42)$.

The liver represents a superior target for F.IX expression for several reasons. In healthy individuals, F.IX is naturally produced in the liver. Hepatocytes have more efficient secretion machinery than myocytes, allowing them to produce higher transgene levels. Most interesting, though, is the fact that liver-directed gene transfer has been shown to induce transgene-specific tolerance that prevents subsequent antibody and $\mathrm{CD} 8^{+} \mathrm{T}$ cell responses $(43,44)$. Further studies have shown that this tolerance is mediated by antigen-specific regulatory $\mathrm{T}$ cells (Treg) (45-47). Tregs are a subset of $\mathrm{CD} 4^{+}$helper $\mathrm{T}$ cells that are typically defined as $\mathrm{CD} 4{ }^{+} \mathrm{CD} 25^{+} \mathrm{FoxP}^{+}$lymphocytes, and are regarded as one of the most important regulators of peripheral tolerance. Through a variety of mechanisms, including cytokine release and contact-dependent interactions, they can prevent immune responses in an antigen-specific manner, though they have also been reported to have polyclonal 
suppressive effects (reviewed in (48)). Though the mechanism of Treg induction is not entirely clear, it can occur for both secreted and cytoplasmic transgenes expressed in hepatocytes, and it depends on both IL-10 and TGF- $\beta(49,50)$. In addition to suppression of de novo immune responses against factor IX, hepatic gene transfer can reverse an active high-titer inhibitor response (4). This mechanism depends on induction of Tregs, and the continued presence of these cells is required to maintain tolerance. The high expression of F.IX in mice following hepatic gene transfer ( $20-40 \%$ of normal) may also be responsible for this rapid clearance of F.IX-specific antibodies due to suppression of memory B cells (4, 51). Though this phenomenon is understandably difficult to verify in human studies, it is encouraging that, to date, none of the patients treated with a liver-directed AAV vector have formed a F.IX-specific immune response $(52,53)$.

However, clinical trials have revealed an additional complication that was not predicted by preclinical studies: the impact of capsid-specific memory $\mathrm{CD}^{+} \mathrm{T}$ cells $(54,55)$. The first clinical trial of hepatic gene transfer with AAV vectors for hemophilia B using an AAV2 vector delivered by injection through the hepatic artery revealed a couple of important findings (52). Contrary to previous expectations, it was found that even low-titer anti-capsid neutralizing antibodies could prevent successful transduction. Additionally, in one patient at the highest dose cohort, an initial rise in circulating hF.IX was detected; however, by 4 weeks post-injection, this expression began to decline with a concomitant rise in liver enzymes indicative of hepatic damage (albeit at asymptomatic levels). By 8 weeks, circulating hF.IX was no longer detectable. Further studies revealed that this decline occurred due to a capsid-specific memory $\mathrm{CD}^{+} \mathrm{T}$ cell response $(52,56)$.

Several advances in AAV vector design were made that were incorporated into the second hepatic gene therapy clinical trial. Rather than using AAV2, this study used an AAV8 vector, a serotype derived from rhesus macaques that has greater liver specificity than AAV2 (31). This allows for elevated transgene expression from an equivalent vector dose, and expression was comparable when the vector was delivered via tail vein or portal vein injection; these greater expression levels also enhanced the F.IX-specific tolerance induced by hepatic gene transfer (57). The prevalence of neutralizing antibodies against AAV8 is lower than AAV2 among the human population, allowing more patients to potentially be treated with AAV8 vectors $(58,59)$. Additionally, a self-complementary AAV (scAAV) vector rather than a single-stranded AAV (ssAAV) was utilized. This modification, performed by mutating one of the viral ITRs, forces the vector to package double-stranded DNA rather than the single-stranded genome found in the wild-type virus (60). These vectors bypass the need for second strand synthesis, a rate-limiting step during AAV transduction, allowing them to produce higher transgene levels $(61,62)$. Expression of hF.IX in mice and non-human primates was elevated with scAAV vectors (63-65).

Somewhat worryingly, recent studies have shown that scAAV vectors induce stronger innate immune responses through toll-like receptor 9 (TLR9) than SSAAV that can enhance transgene-specific immune responses during transfer to skeletal muscle (66-68) (reviewed in (69)). Similarly, the removal of CpG motifs sensed by TLR9 from the vector genome can allow expression in skeletal muscle by preventing the formation of a $\mathrm{CD}^{+} \mathrm{T}$ cell response against LacZ (70). In hemophilic mice with a null mutation, we found that scAAV enhances 
$\mathrm{CD}^{+} \mathrm{T}$ cell but not antibody responses to hF.IX following intramuscular gene transfer (71). However, in transgenic hemophilic mice that are partially tolerant to hF.IX due to expression of truncated, nonfunctional hF.IX, no immune response was observed regardless of the vector genome, suggesting that the enhanced immunogenicity of scAAV vectors may not break tolerance when administration with ssAAV is tolerated. This was also true during hepatic gene transfer, where the enhanced innate immune response to scAAV did not result in transgene-specific immune responses (67). Unlike adenoviral vectors, the innate immune response from scAAV was not sufficient to induce type I interferon-dependent transgene silencing (72). However, the innate immune response may not always be deleterious, as activation of the alternative $\mathrm{NF}-\kappa \mathrm{B}$ pathway has been shown to enhance transgene expression from AAV vectors (73).

Thus, the second clinical trial of hepatic gene therapy for hemophilia B used a scAAV8 vector delivered via peripheral vein injection (53). As previously observed, a rise in liver enzymes was detected only in subjects treated at the highest dose, though at around 8 weeks rather than 4 weeks post-injection. Administration of prednisolone at this time was able to suppress the $\mathrm{CD}^{+} \mathrm{T}$ cell response against the AAV capsid, allowing F.IX activity to persist at around $2 \%$ of normal. In a subsequent subject, more careful monitoring around this time point allowed the prednisolone treatment to preserve F.IX expression at $\sim 5 \%$ normal. These data represent the first successful clinical gene therapy for hemophilia B. Although this treatment appears to have been successful, there are still problems that limit its applicability.

First, many hemophilia patients, particularly those infected with hepatitis $\mathrm{C}$, are not eligible for general steroidal immune suppression. To this end, several alternatives are being studied in animal models. Targeting of hepatocytes by capsid-specific cytotoxic T lymphocytes (CTLs) requires the degradation of input viral capsid, as the recombinant vectors do not encode for any viral proteins. This process occurs primarily through proteasomal degradation, which is provoked by phosphorylation and subsequent ubiquitination of the AAV capsid $(74,75)$. The role of the proteasome is supported by a recent study demonstrating that presentation of AAV capsid epitopes in MHC class I (allowing the cell to be targeted by capsid-specific CTLs) requires endosomal escape into the cytoplasm but is independent of nuclear uncoating, suggesting that this degradation occurs in the cytoplasm (76). To avoid this process, mutant AAV2 capsids have been developed in which tyrosine residues have been mutated to phenylalanine (77). Specifically, a combination of three mutations (Y444+500+730F) allows for greatly enhanced transgene expression both in vitro and in vivo (78). In addition to enhancing transduction, these vectors reduce the ability for capsid-specific $\mathrm{CD}^{+} \mathrm{T}$ cells to target transduced hepatocytes (79). Adoptive transfer of ex vivo expanded capsid-specific CTLs to immune-deficient mice resulted in more residual hF.IX expression and less elevation in liver enzymes in mice transduced with AAV2(Y-F) vectors than wild-type AAV2. This effect could be further enhanced with a proteasome inhibitor. Interestingly, AAV8 vectors showed prolonged vulnerability to CTL targeting, and additional studies have suggested that, depending on the vector genome, $\mathrm{CD} 8^{+} \mathrm{T}$ cells can detect AAV8 for as long as 6 months in mice $(79,80)$. This difference in the kinetics of antigen presentation between AAV2 and AAV8 may explain the delay in CTL response observed in the second clinical trial for hepatic gene transfer relative to the first. 
The other limitation of the current approach is its inability to treat patients with pre-existing neutralizing antibodies (NAB) to AAV8 (reviewed in (81)). Following the first hepatic clinical trial, it was discovered that NAB titers as low as 1:5 could severely impact transgene expression in vivo (82-84). Additionally, even if patients initially lack NAB, after the vector injection they will develop an anti-capsid antibody response that will prevent readministration of the vector. Several approaches have been investigated to negate the impact of NAB. Attempts have been made to modify the AAV capsid itself, both by rational design and directed evolution, to negate its susceptibility to NAB binding $(85,86)$.

Plasmapheresis has shown some success at removing NAB from sera, particularly with repeated cycles, though the ability to reach titers sufficiently low to allow transduction may be restricted to individuals with initially low titers $(<1: 100)(87,88)$. Isolation of the liver using balloon catheters and delivering the vector via portal vein injection may also increase the success of gene transfer in the presence of NAB (89). Pharmacological approaches have primarily focused on the use of rituximab, a monoclonal antibody against CD20 that is currently approved for B cell depletion in several autoimmune diseases and B cell cancers. Rituximab alone was able to partially reduce AAV NAB titers in patients with rheumatoid arthritis, though most subjects did not drop below a titer of 1:5 (90). These residual NAB are likely due to an incomplete depletion of B cells by rituximab, as well as the fact that plasma cells do not express CD20, rendering them immune to the cytotoxic activity of rituximab (91). In nonhuman primates, a combination of rituximab and cyclosporine A was more effective at eliminating NAB (92). Additionally, a non-depleting anti-CD4 antibody prevented the development of NAB following AAV gene transfer, though the effects on preexisting anti-capsid antibodies remain to be seen (93). Finally, the second hepatic clinical trial revealed an interesting phenomenon: although expression levels at the highest dose in both trials were similar, circulating hF.IX expression was observed at low doses in the second trial but not the first. Interestingly, the vector formulation in the second trial contained empty AAV capsids lacking DNA, a byproduct of rAAV production that was removed during the previous trial. Thus, Mingozzi et al. have found that the addition of empty capsids can serve as a decoy for pre-existing NAB, with higher titers requiring a greater excess of empties relative to the DNA-containing capsids (94). These empty capsids have been modified to remove the binding site that allows entry into hepatocytes, though it remains to be seen whether this will prevent these decoy capsids from enhancing the $\mathrm{CD}^{+}$ $\mathrm{T}$ cell response in human studies (95). As these various approaches each seem to be partially effective, it is possible that some combination of them (or a yet undiscovered therapy) will allow us to bypass NAB and make AAV gene therapies available for patients with preexisting immunity.

Great strides have already been made in clinical trials for AAV-mediated gene therapy for hemophilia B. Earlier intramuscular studies provided a proof of concept and safety information, while liver-directed gene delivery has seen greater success, though it can still be limited by both NAB and anti-capsid CTL responses (Figure 4). However, there are still problems to solve to improve this strategy, as indicated by the fact that, in addition to the two completed trials, there are currently three active clinical trials using AAV vectors to treat hemophilia B (Table 1). 


\subsection{Retrovirus and Lentivirus}

Although the most clinical success to date has been seen with AAV, numerous studies have also been performed using integrating viral vectors to treat hemophilia B. Unlike AAV, where the maximum duration of expression and stability of episomal concatemers is not yet known, expression from an integrating vector would persist as long as cells from the transfected lineage remain. However, integration also comes with the risk of insertional mutagenesis. Initially, studies focused on the use of $\gamma$-retroviral vectors based on Moloney murine leukemia virus (MMLV); however, the inability of these viruses to transduce nondividing cells as well as their propensity for oncogenesis, as seen in a clinical trial for SCID-X1, has caused these vectors to be looked on less favorably $(96,97)$. Rather, research has shifted focus towards lentiviral vectors (LV). LV is based on HIV-1 (reviewed in (98)). Like $\gamma$-retroviral vectors, $L V$ is an integrating ssRNA vector with a packaging capacity of $\sim 10 \mathrm{~kb}$. Unlike the former, though, LV can transduce non-dividing cells (99). Pseudotyping the virus with various envelope proteins allows for significant alterations to tissue tropism and biodistribution. LV is most commonly pseudotyped with the VSV-G protein from vesicular stomatitis virus, though proteins from other viruses-including filovirus, Ebola, LCMV, and rabies virus-have also been employed (100-102). VSV-G pseudotyping allows for transduction of a wide variety of cell types both in vitro (e.g. CD34+ stem cells) and in vivo (e.g. liver, brain, and muscle). The integration pattern of $\mathrm{LV}$ is somewhat random, though biased towards transcriptional units. Compared to $\gamma$-retroviral vectors, which preferentially integrate into transcription start sites, LV prefers to integrate further into the active transcription unit $(103,104)$. Additionally, some LV incorporate a mutation that eliminates the transcriptional activity of the long terminal repeats; these LV are termed selfinactivating (SIN) (105). Although this modification can also reduce the oncogenicity of $\gamma$ retroviral vectors, studies in a cancer-prone mouse model have suggested that integration levels as much as 10-fold higher may be required for LV to reach similar oncogenic potential to $\gamma$-retroviral vectors (106-108). Overall, although it is clear that there are risks associated with integrating vectors, the exact degree of risk is currently unclear (109).

One significant advantage of an integrating vector is that it can be applied to cells ex vivo, and the transduced cells can then be reintroduced, bypassing any interference from an immune response against the virus (Figure 5). While this strategy is more often applied to gene therapy for hemophilia A, some research has also been done with ex vivo gene transfer for hemophilia B. The most common target for this type of therapy is hematopoietic stem cells (HSCs), due to the ease of both harvesting and reintroducing these cells. Following up on earlier studies performed with F.VIII, it was shown that gene transfer to bulk HSCs using $\mathrm{LV}$ resulted in sustained F.IX expression that tolerized recipient mice to hF.IX and could be transferred to secondary and tertiary recipients $(110,111)$. A similar outcome was achieved by targeting expression to cells of the erythroid lineage (112). However, in both studies, mice were lethally irradiated in order to allow engraftment of the transfected HSCs (111, 112). To enhance the clinical relevance of this approach, a dual expression LV expressing both $\mathrm{hF} . \mathrm{IX}$ and a drug resistance gene (methylguanine methyltransferase mutant P140K, MGMT) was used to achieve correction following engraftment with a moderate busulfan conditioning that was nonmyeloablative $(113,114)$. In addition to erythroblasts, F.IX expression has also been investigated in platelets following the success seen with that 
strategy for F.VIII (115). A transgenic mouse expressing F.IX in platelets demonstrated correction of the bleeding phenotype (116). However, unlike with F.VIII, the activity of F.IX expressed in platelets was still adversely affected by inhibitory antibodies. This effect can also be achieved with gene transfer using LV, and this strategy induces tolerance to $\mathrm{hF} . \mathrm{IX}$ in treated mice as well (117). More recently, studies have begun to explore expression in alternative types of stem cells. Treatment of murine adipose tissue-derived stem/stromal cells (mADSCs) with LV can induce sustained hF.IX expression in vitro, though it remains to be seen whether these cells can engraft into a recipient and provide sustained correction (118). Similarly, menenchymal stem cells (MSCs) derived from human cord blood can be transduced with retroviral or LV vectors to produce F.IX in vitro and in vivo, though efforts are still underway to optimize the matrix for cell growth and F.IX production (119-122).

In addition to ex vivo gene transfer, LV can also be employed for in vivo gene therapy. Although some studies have attempted to deliver LV prenatally to induce F.IX expression, these approaches have mostly focused on inducing the expression of F.IX in hepatocytes (123-125). Early studies demonstrated that it is possible to induce sustained hF.IX expression in hepatocytes using $\mathrm{LV}$, and that proliferation is not required for transduction (126-129). F.IX expression has also been induced in vivo under the control of tetracycline using LV (130). However, as with AAV, in vivo gene transfer revealed barriers to transduction set up by the immune system. Unlike with AAV vectors, hepatic gene therapy with $\mathrm{LV}$ did not initially induce tolerance to the transgene. It was discovered that, due to their broad tropism, VSV-G-pseudotyped vectors could transduce antigen-presenting cells (APCs) (131). Since then, a number of steps have been taken to enhance the specificity of expression from LV. The use of a liver-specific promoter allowed for sustained expression of F.IX, but still did not completely eliminate off-target transduction (132). Nonspecific expression in APCs could be further reduced by adding target sequences for a hematopoietic-specific microRNA (miR-142) to the transcript. Mice treated with miR-142regulated LV showed sustained expression of hF.IX and remained nonresponsive following immunogenic challenge, suggesting that they had been tolerized to hF.IX via a mechanism mediated by regulatory $\mathrm{T}$ cells $(133,134)$. Similar to what was found with AAV vectors, hepatic expression of F.IX via LV was also able to reverse an active inhibitor response, suggesting that hepatic gene transfer can be both therapeutic and tolerogenic even in the presence of an active immune response (135).

As with AAV, eliminating barriers to transduction posed by the adaptive immune system revealed deleterious effects of innate immunity on LV gene transfer. In vivo administration of LV triggers type I interferon (IFN) responses that restrict gene transfer and promote vector clearance (13). Consistent with previous in vitro findings, this mechanism was shown to be partially dependent on TLR7, which senses the ssRNA genome of LV $(14,136,137)$. However, TLR-independent innate immune responses were detected as well (14). Through the use of a reverse-transcriptase inhibitor, it was suggested that these responses were due to the cytoplasmic sensing of viral DNA. Recently, cyclic GMP-AMP synthetase (cGAS) has been implicated as a sensor of cytoplasmic DNA with crucial roles both in vitro and in vivo (138-142). Interestingly, cGAS has been reported to induce type I IFNs in response to HIV 
and other retroviruses, suggesting that it may be responsible for this TLR-independent innate immune response to LV (143).

Aside from concerns of immunogenicity, the most important safety concern for LV remains the risk of insertional mutagenesis. Although the degree of risk remains a matter of debate, the potential for tumorigenesis following LV gene therapy has not been eliminated (144). To this end, integrase-defective lentiviral vectors (IDLV) have been developed; expression occurs from these viruses without integration at a rate above random (145-148). The viral genome is stable in episomal form, persisting in nondividing cells but not actively dividing cells (149-151). These findings were confirmed by in vivo studies with F.IX. Although the transduction efficiency of IDLV was lower than integrating LV, hepatic expression of F.IX using IDLV is able to induce antigen-specific tolerance and reverse an active inhibitor response $(135,152)$. However, expression subsided precipitously following partial hepatectomy, indicating a lack of integration. Additionally, in normal mice, F.IX levels declined significantly by 1 year post-injection, suggesting that transgene expression would not be persistent (152). Thus, while F.IX expression can be induced by IDLV, it seems likely that further development of these vectors to achieve persistent expression will be required for them to be a potential therapy for hemophilia B.

\subsection{Integrases and non-viral approaches}

In addition to the viral gene therapies we have discussed previously, nonviral gene therapy has also been investigated for hemophilia B. At its simplest, this involves the delivery of naked plasmid DNA to target cells. Although modern viral vectors do not produce any viral proteins in target cells, the delivery of naked DNA would also eliminate the immunogenicity of the input viral proteins (such as the $\mathrm{CD}^{+} \mathrm{T}$ cell response to the AAV capsid). However, the problems with this approach are twofold. Firstly, transgene expression from nonviral delivery is typically lower than seen with viral vectors, and without selective pressure or incorporation of the exogenous DNA, expression is short-lived (153). Secondly, it can be challenging to get the DNA into the target cells of interest. In vitro, membrane-disrupting procedures such as electroporation and liposome transfection can be employed. For in vivo targeting, although a number of targeting approaches are currently under development, hepatic gene transfer is most commonly achieved by hydrodynamic injection of a high volume of DNA solution intravenously (154-157). Efforts are underway to adapt this procedure to larger animal models and eventually humans (158-163).

To bypass the transient nature of plasmid DNA approaches, investigators have recognized the emerging potential of transposons to generate long-lived expression (164). Transposons are naturally occurring DNA elements capable of moving from one chromosomal location to another. They do so by encoding a transposase, a protein which is able to excise the transposon from the donor locus and insert it into a target location. Transposases can act on any DNA sequence flanked by the specific terminal repeat sequences, allowing for integration when DNA encoding for the transposase is added along with the transgene flanked by terminal repeat sequences. Research for gene therapy applications have primarily focused on two transposons: piggyBac (derived from the cabbage looper moth Trichoplusia $n i)$ and Sleeping Beauty (SB; a Tc1-like transposon from fish), as well as its hyperactive 
mutant, termed SB100X (165-170). The relative activity of these two transposons remains controversial, though it is likely that the rate of integration depends on the cell type being transduced $(171,172)$. However, it is known that these transposons have distinct integration patterns. SB appears to integrate randomly, whereas piggyBac is biased towards transcriptional start sites, similar to the integration pattern of viral vectors (173-175). By incorporating SB into IDLV, it is possible to replicate this random integration pattern with a viral vector (176). Like LV, the untranslated regions of SB possess transcriptional activity, and incorporation of insulator sequences into this region can reduce the risk of transcriptional activation of host genes proximal to the insertion site (177).

Gene therapy with transposons can be performed directly in vivo, or applied ex vivo to cells which are then reintroduced into the host. However, likely due to the greater success seen by in vivo approaches in gene therapy for hemophilia $\mathrm{B}$, transposon research has focused on that approach. Using hydrodynamic injection, delivery of a SB-containing plasmid along with a plasmid containing F.IX transgene resulted in robust long-term hF.IX expression in mice (178). Similarly, hydrodynamic gene transfer using the $\Phi C 31$ integrase (derived from a bacteriophage) induced persistent F.IX expression in hemophilic mice (179-181). However, as previously mentioned, this procedure is currently not applicable to larger animal models. Ironically, in order to achieve targeted delivery of transposon/integrase systems, some investigators have returned to viral vectors. For instance, engineered adenoviral vectors incorporating SB transposons have been used to achieve sustained F.IX expression in mice and in hemophilic dogs (182-184).

Although these approaches have shown some success in pre-clinical models, even the random integration profile of SB transposons is not ideal, as it still carries the potential for oncogenesis. Ideally, targeted integration into 'safe harbor' sites in the genome that are not oncogenic would be employed to eliminate this risk. PiggyBac transposons have been shown to tolerate N-terminal fusion of DNA-binding domains that should constrain its activity to that specific region of the chromosome, whereas a molecular bridge can be employed with SB to fuse it to a DNA-targeting protein $(171,185)$. Alternatively, targeted gene delivery has been achieved using artificial DNA-recognizing proteins (reviewed in (186)). Zincfinger nucleases (ZFNs) based on naturally occurring DNA-binding motifs can be engineered to recognize specific DNA sequences by linking together domains that bind specific 3 base pair sequences, allowing for a sequence of 9-18 bp to be identified that should be unique within the human genome (187-189). Similarly, transcription activator-like effector nucleases (TALENs), composed of 33-35 amino acid repeat domains, are able to recognize single base pairs to construct a DNA recognition sequence $(190,191)$. Finally, the recently discovered clustered regularly interspaced short palindromic repeats (CRISPR)/ CRISPR-associated (Cas) systems, which are normally used by bacteria as an adaptive immune system to specifically target phage DNA sequences, use RNA base pairing to DNA to target their cleavage activity (192-197). These targeted DNA integration strategies can approach gene correction in two ways. In addition to the traditional approach of introducing an intact transgene to a safe harbor locus, it is also possible to directly target to mutated gene, replacing it with the corrected sequence (198-200). This second approach may be superior in that it allows the corrected gene to utilize all of the natural regulatory elements of 
the gene, such as upstream enhancers that likely would not act on the transgene otherwise. However, it also requires specific design and validation of the targeting nuclease for each disease, whereas insertion into a safe harbor locus could employ the same nuclease while only changing the gene within the delivery vector.

Delivery of these DNA-targeting nucleases remains an issue, as with transposons. Thus, in the treatment of hemophilia $\mathrm{B}, \mathrm{AAV}$ vectors have been used to deliver a $\mathrm{ZFN}$ in conjunction with the hF.IX transgene (201). This genome editing approach cleaved the endogenous F.IX gene after exon 1 (the excised portion encompasses $95 \%$ of mutations) and replaced the defective gene with the corrected sequence. Due to the limited packaging capacity of AAV, a dual-vector approach had to be employed in which two AAV vectors were injected simultaneously, one containing the transgene while the other encoded for the ZFN. Although this approach should lead to sustained expression of the ZFN, no adverse consequences (offtarget mutations, excision of the transgene, etc.) were observed. This study was initially performed in neonatal mice. Due to their actively growing liver, neonates were anticipated to be capable of homology-directed repair in hepatocytes rather than favoring nonhomologous end joining as in quiescent cells $(202,203)$. However, further investigation determined that this genome editing approach is also effective in adult mice (204).

Finally, a novel approach for nonviral gene therapy involves the oral delivery of plasmid DNA coding for $F 9$ encased in chitosan nanoparticles (205). In a mouse model of hemophilia B, this approach could induce circulating F.IX and correction of the coagulation defect, particularly when using hyperactive F.IX mutants (206). F.IX expression was restricted to the small intestine. However, despite the tolerogenicity of oral protein delivery, this oral DNA delivery approach was not able to prevent inhibitor formation following protein challenge nor reverse pre-existing inhibitors (206-208).

\subsection{Optimization of factor IX}

A more recent development in gene therapy for hemophilia B involves alterations to the $F 9$ transgene itself rather than the delivery vector, a strategy which is applicable regardless of the delivery mechanism chosen. There are a couple potential strategies to achieve this. First, and already in use in the second hepatic clinical trial, is codon optimization $(53,64)$. This technique is based on the fact that, despite multiple trinucleotide sequences encoding for a single amino acid, certain codons are preferred over others depending on the host organism (mostly due to tRNA frequencies) (209). By making silent mutations within the transgene, it is thus possible to increase translation efficiency by optimizing codon usage for the target cell; this strategy also allows for other changes, such as the removal of negative regulatory cis-acting features, to enhance expression (210). Codon optimization of F.IX was reported to increase expression 3-4-fold compared with the unaltered sequence (63). More specific to F.IX, though, is the discovery of mutants with increased clotting activity. Alanine substitution mutation resulted in the artificial generation of F.IX-triple, which has $\sim 10$-fold greater specific activity than wild-type F.IX $(211,212)$. Additionally, a naturally occurring F.IX mutation (R338L), termed F.IX Padua, was discovered that has 5-10-fold higher activity $(42,213-215)$. Although these hyperactive F.IX variants can cause thrombosis at physiological expression levels, the fact that F.IX circulates in plasma in an inactive form 
makes them apparently safe at the expression levels achieved by gene therapy ( $~ 5-10 \%$ of normal). Interestingly, both variants possessed a mutation at amino acid 338: alanine in F.IX-triple and leucine in F.IX Padua. Adding the leucine mutation to F.IX-triple resulted in an even better clotting factor, with activity $\sim 15$-fold greater than normal F.IX (216). A clinical trial is currently underway using an AAV8 vector containing F.IX Padua (NCT01687608).

\section{GENE THERAPIES FOR HEMOPHLIA A}

In contrast to hemophilia $\mathrm{B}$, gene therapy for hemophilia A has seen significantly less recent progress into the clinic, despite it being the more common of the two diseases. Although the vector platforms and advances within them that we have previously discussed for hemophilia B should also be applicable for hemophilia A, there are some additional factors that make endogenous expression of F.VIII more complicated than F.IX. We will subsequently examine some of these issues before discussing the progress that has been made with various vector systems towards a genetic therapy for hemophilia A.

\subsection{Additional challenges in hemophilia $A$}

The primary difficulties in gene therapy for hemophilia A stem from the fact that F. VIII is a much more complicated protein than F.IX. As opposed to the single domain of F.IX, F.VIII is produced as a 2351 amino acid protein (encoded by a $9 \mathrm{~kb}$ cDNA) that, following secretion, is cleaved into a noncovalent heterodimer of two chains: the heavy chain (A1-A2B domains) and the light chain (A3-C1-C2 domains) (217). The size and complexity of F.VIII lead to several complications for gene therapy. First, a $9 \mathrm{~kb}$ transgene is too large for some vector systems, such as AAV. Additionally, the synthesis and secretion of F.VIII is notoriously inefficient. Using a comparable retroviral vector delivery system, the levels of F.VIII produced in vitro were about 2 orders of magnitude lower than F.IX (218). The inefficiency of F.VIII production results from several factors, including inefficient expression of the mRNA, misfolding and degradation of the translated protein, and retention in the endoplasmic reticulum via binding to ER chaperones such as immunoglobulin binding protein (BiP) (218-225).

The synthesis of F.VIII is further complicated by the interaction with von Willebrand factor (vWF), which is required for stabilization of F.VIII $(226,227)$. Studies in vitro have suggested that this stabilizing effect is enhanced when F.VIII and vWF are co-expressed in the same cell, rather than simply adding vWF to the media $(219,228)$. However, while vWF is believed to be produced in endothelial cells, platelets, and megakaryocytes, the site of F.VIII synthesis is somewhat controversial (229-231). The liver has been implicated as a major site of F.VIII synthesis due to the ability of liver transplantation to cure hemophilia A in canine models as well as human patients (232-234). A number of studies have reported the presence of F.VIII mRNA and protein in hepatocytes in vivo, F.VIII production by hepatocytes cultured in vitro, and even the ability to restore clotting activity through hepatocyte transplantation (235-239). Conversely, others have reported F.VIII synthesis in liver sinusoidal epithelial cells (LSECs) but not hepatocytes, or even in both cell types (240-246). However, the preponderance of recent evidence implicates LSECs and by extension endothelial cells in other tissues as well, which may explain the observations of 
F.VIII production in extrahepatic vascularized tissues such as the kidney, spleen, and lung (247-250). In particular, a pair of recent studies using conditional knockout mice demonstrate a requirement for endothelial cells but not hepatocytes in F.VIII synthesis (251, 252). Thus, the combination of expression in an unnatural cell type and the lack of vWF synthesis in hepatocytes may explain the difficulties that have been encountered in inducing hepatic expression of F.VIII using techniques that have been successful with F.IX.

Although these findings suggest that endothelial cells might be a preferred target for F.VIII expression, moving gene expression away from hepatocytes potentially highlights complications from the immune response to the transgene that are not a factor following hepatic gene transfer. The strength of tolerance induction to F.IX following hepatic gene transfer for hemophilia B is proportional to transgene expression levels $(4,57)$. Tolerance to F.VIII following gene transfer is likely also mediated by a similar Treg-dependent mechanism (253). Thus, in addition to the difficulty in achieving therapeutic correction, the low expression levels of F.VIII following gene transfer also reveal challenges from the immune system. The endogenous levels of F.IX in plasma $(5000 \mathrm{ng} / \mathrm{mL})$ are already significantly higher than F.VIII (200 ng/mL). When this gap is further enhanced by low expression of F.VIII following hepatic gene transfer, hemophilia A mice can generate inhibitors against F.VIII or even be potentiated towards stronger immune responses to i.v. protein challenge than their untreated brethren (254-258). Furthermore, F.VIII seems to be naturally more immunogenic than F.IX, since hemophilia A patients develop inhibitors at about 5-6 times the rate of hemophilia B patients during recombinant protein therapy. Conversely, other studies have suggested that tolerance to F.VIII following hepatic gene transfer with LV may occur or persist in the absence of transgene expression (259).

However, these mice were transduced as neonates; the protocol was not tolerogenic in older mice or with non-hepatic delivery routes.

While there are many similarities between hemophilia A and B, these additional difficulties in achieving therapeutic circulating expression and dealing with the immune response to F.VIII have complicated attempts to develop a gene therapy for the former. Keep these challenges in mind as we begin our discussion of the specific approaches used in gene therapy for hemophilia A, as surmounting them has required novel developments and led to some unique approaches that are not effective for hemophilia B.

\subsection{Adeno-associated virus}

Given the success that AAV has shown as a vector for the treatment of hemophilia B, it is logical that a number of approaches have also attempted to use it for hemophilia A. When considering AAV-mediated delivery of F.VIII, the most pressing concern is the issue of packaging capacity-AAV vectors cannot package the entirety of the $F 8$ gene. Two strategies to circumvent this limitation have been explored. Firstly, the heavy and light chains of F.VIII can be split into separate vectors, and co-injection of these AAVs can induce the expression of biologically active F.VIII in circulation (260). However, the utility of this approach is limited by the fact that the F.VIII light chain can interact with the heavy chain within the cell, significantly enhancing secretion $(261,262)$. Thus, only cells that are transduced by both vectors are likely to be involved in F. VIII production. Alternatively, the 
use of a shortened promoter sequence allows the packaging of B-domain-deleted (BDD) F.VIII within a single AAV particle $(256,263)$. BDD F.VIII, as the name implies, is produced by removing the B domain of the $F 8$ gene. This alteration does not appear to have any adverse effects on procoagulant activity of the protein (264). As the B domain represents over a third of the F.VIII protein, its removal results in a cDNA that can be packaged in an AAV vector and induce sustained F.VIII expression in mice $(256,265)$. These findings have been replicated in studies in hemophilic dogs, $(266,267)$. Further studies have indicated that both approaches (BDD and dual-vector F.VIII) can be effective in canine models $(268,269)$. However, the doses needed to achieve therapeutic correction were significantly higher than the maximum dose of AAV-F.IX administered to humans in clinical trials $(52,53,270)$. Given the dose-dependence of the memory $\mathrm{CD} 8^{+} \mathrm{T}$ cell response to capsid that was observed in these trials, these vector doses may not be feasible in human subjects.

By enhancing the expression per AAV particle, it may be possible to reduce this dose. For instance, the use of a full-length rather than a truncated promoter is able to enhance F.VIII expression from AAV vectors (271). Although this required the use of an oversized AAV genome $(5.75 \mathrm{~kb})$, some studies have suggested it is possible to produce AAV vectors with an oversized genome, albeit at the cost of reduced packaging efficiency $(272,273)$.

However, further investigation has suggested that these vectors do not actually package oversized genomes; rather, the transgene is fragmented between AAV vectors and complementation in the cell following transduction results in expression of these oversized transgenes (274-277). Thus, this approach would likely be subject to the same limitations as splitting the chains into separate vectors. That expression depends on transduction of a single cell by two separate AAV vectors significantly reduces expression levels below what they would otherwise be. Since proteasome inhibitors can increase transduction by AAV, the use of bortezomib can enhance expression of F.VIII using these oversized AAV vectors $(74,75,278-280)$. Additionally, the use of a more strongly liver-specific promoter can enhance transgene expression while simultaneously reducing the propensity for inhibitor formation that can occur with a ubiquitous promoter (281). Similarly, neonatal administration of AAV avoided immune responses against F.VIII (282). Codon optimization of F.VIII significantly enhances transgene expression, as with F.IX (283). In HA mice, a dose used in humans $\left(2 \times 10^{12} \mathrm{vg} / \mathrm{kg}\right)$ of AAV containing codon-optimized F.VIII with a liver-specific promoter induced supraphysiologic F.VIII expression (284). However, even codon-optimized F.VIII is subject to limitations imposed by the immune system. The immunogenicity of codon-optimized F.VIII can vary depending on the genetic background of the treated hemophilic mice (257). In NHP, therapeutic expression was also induced; however, 3 out of 4 macaques developed inhibitors against F.VIII that were resolved with transient immunosuppression (284). Although AAV-mediated gene therapy for hemophilia A is progressing, the immune response to the transgene clearly still represents an additional barrier to transduction that is not fully understood yet.

\subsection{Retrovirus and Lentivirus}

In addition to AAV, significant work has been done exploring the use of retroviral/lentiviral vectors for the treatment of hemophilia A. As previously mentioned, these vectors can be 
employed for either ex vivo or in vivo gene transfer. The first proof of concept for in vivo gene therapy used a $\gamma$-retroviral vector to express F.VIII in hepatocytes of neonatal hemophilic mice (285). This approach was also successful in a canine model of hemophilia A (286). Though additional studies in mice and rabbits suggested that this approach may also be viable in adult subjects, in human patients, only a sporadic and transient rise in circulating F.VIII was detected (287-289). In addition to $\gamma$-retroviral vectors, LV has also been employed in the treatment of hemophilia A via in vivo gene transfer. Although F.VIII expression can be achieved with this approach, the therapeutic benefit was hampered by the subsequent development of anti-F.VIII inhibitors in immune competent mice (126, 290-292). Feline immunodeficiency virus (FIV)-based LV have also been employed for hemophilia A gene therapy; these studies have suggested that pseudotyping with the GP64 envelope protein from baculovirus may enhance liver tropism of LV (293-295). By combining this liver-tropic envelope protein with a liver-specific promoter and miR-142 regulation (to prevent transgene expression in APCs), it was finally possible to use LV to express F.VIII in hepatocytes without provoking an inhibitor response (296). Continuing the theme of enhanced immunogenicity of F.VIII relative to F.IX, the GP64 envelope protein was required to avoid inhibitor formation in this case, whereas the F.IX-expressing LV could achieve safe expression with a VSV-G envelope protein $(133,296)$. Although the miR-142-regulated LV expressing F.IX was tolerogenic, preventing antigen-specific immune responses, it remains to be seen whether these F.VIII-expressing vectors can also prevent inhibitor formation following challenge with recombinant protein $(134,135)$. Given the ability of AAV-F.VIII vectors to potentiate stronger immune responses in some strains of HA mice, this is a relevant concern if subsequent supplementary doses of F.VIII are required (257). Lastly, although LV vectors have been developed that target gene delivery to endothelial cells in vivo, the efficacy of this approach for F.VIII expression remains to be seen $(297,298)$.

Among the ex vivo gene therapies using LV, the most common site of expression is hematopoietic stem cells. Expression of F.VIII in hematopoietic stem cells has been achieved as early as 1992 using $\gamma$-retroviral vectors; although this approach did not initially correct the bleeding phenotype in vivo, it did appear to partially tolerize mice to F.VIII (299, 300). Further optimizations allowed for therapeutic F.VIII expression in vivo, as well as enhanced efficacy of the tolerogenic potential of this treatment (301-304). Similarly, LV can be used to induce F.VIII expression in hematopoietic stem cells as well as human CD34 ${ }^{+}$ cord blood cells (305-308). LV-mediated F.VIII expression in B cells also induces therapeutic F.VIII expression and immune hyporesponsiveness (309). An interesting development involves the expression of F.VIII specifically in platelets rather than all hematopoietic cells. Outside of endothelial cells, platelets are the other major source of vWF; platelet-derived vWF is thought to be critical for on-demand coagulant activity, though it may also play a role in clotting hemostasis (310). Given the ability of vWF to enhance F.VIII secretion, producing F.VIII within platelets may allow for efficient ondemand release of F.VIII (311). A transgenic mouse expressing F.VIII under the control of a platelet-specific promoter demonstrated correction of the bleeding phenotype in the absence of circulating F.VIII (312). LV can be used to express F.VIII specifically in platelets, and this strategy also provides therapeutic benefit in the absence of circulating F.VIII $(313,314)$. 
This approach has also proven effective in canine models of hemophilia, and LV-transduced human cord blood cells correct the bleeding phenotype when transplanted into immunodeficient hemophilic mice $(315,316)$. A surprising consequence of this approach to deliver F.VIII on-demand following a bleeding incident is the ability to bypass concerns of immunogenicity that have plagued other approaches. Mice treated with LV to induce F.VIII expression in platelets show bleeding correction even in the presence of high-titer inhibitory antibodies (317). Transduced mice more rapidly clear inhibitors compared to control animals, though they still had clinically relevant Bethesda titers $(B U>5)$ six months postinjection. Additionally, the consequences of challenge with recombinant protein remain to be seen. This is in contrast to HSC transduction with retroviral vectors and a less restrictive promoter, which robustly induced tolerance to the transgene (303). The efficacy of tolerance induction following HSC gene transfer appears to be directly correlated with the efficiency of engraftment/expression. The use of safer vectors, more restrictive promoters, or milder conditioning regimens seems to impede the ability to induce transgene-specific tolerance, perhaps suggesting that transgene expression in specific hematopoietic cell types is required for tolerance induction $(17,318)$. Moreover, other studies have suggested that the ability of platelet-derived F.VIII to bypass inhibitors is improved but limited relative to plasma F.VIII (319). The efficacy of platelet-derived F.VIII can vary depending on the bleeding model used, so further preclinical studies will be required to validate this approach for use in humans (320).

In addition to HSCs, mesenchymal stem cells (MSCs) can be transduced by retroviruses to produce F.VIII $(321,322)$. In mice, MSCs transduced via LV to express F.VIII were not able to mediate systemic correction; however, following intra-articular injection, they were able to reduce bleeding following joint capsular needle puncture injury (323). When LVtransduced MSCs were injected intraperitoneally into hemophilic sheep, however, they demonstrated widespread engraftment in organs and joints and were able to prevent further spontaneous bleeding as well as resolving pre-existing joint damage (324). In addition to hematopoietic approaches, LV has also been used for ex vivo transduction of endothelial cells to produce F.VIII. Although this approach avoids the need for myeloablative conditioning, which can have deleterious side effects, achieving persistent engraftment of endothelial progenitors has been challenging (325). Recent developments in cell sheet transplantation technology have shown promise for achieving sustained F.VIII expression from transduced endothelial cells (326). However, in a canine model, it was recently suggested that the use of an implantation matrix may not always be desirable. Omental implantation of F.VIII-expressing endothelial cells transduced with LV in a fibrin matrix induced an inhibitor response in the presence of sustained F.VIII expression, possibly due to the induction of IL- 6 and MCP-1 by the thrombin in the matrix (327). Although anti-F.VIII IgG2 antibodies were detected when cells were implanted in the absence of this matrix, they did not possess inhibitory activity. Finally, LV has recently been used to transduce induced pluripotent stem (iPS) cells. While these iPS cells, which are transcriptionally reprogrammed from adult cells, show some promise, there are still a number of barriers including oncogenicity, genomic instability, epigenetic memory, and the impact of propagation in culture that caution against the use of these cells (328). In nude mice, LVtransduced iPS cells were capable of teratoma formation and the secretion of physiologically 
relevant levels of functional F.VIII (329). The impact of the immune system on this approach, however, is still unknown.

\subsection{Integrases and non-viral approaches}

Research in nonviral gene therapy for hemophilia A has largely mirrored the approaches used for hemophilia B. In vivo hydrodynamic injection of F.VIII-expressing plasmid can induce transgene expression; however, unlike with F.IX, this approach is limited by the development of anti-F.VIII inhibitors (254). Subsequent studies with the addition of immunomodulatory therapies have prevented inhibitor formation and induced F.VIIIspecific tolerance mediated by Tregs $(255,330,331)$. Hydrodynamic injection in conjunction with RNA trans-splicing (splicing therapeutic RNA into abundant albumin mRNA) has also been explored in the treatment of hemophilia A $(332,333)$. Similarly, sustained gene transfer using the Sleeping Beauty transposon is limited by an immune response to F.VIII, unless tolerance is induced at the neonatal stage $(334,335)$. Interestingly, in adult mice, using SB to express both F.VIII and the immunosuppressive enzyme indoleamine 2,3-dioxygenase (IDO) induced sustained F.VIII expression and reduced T cell infiltration in the liver (336). In addition to hydrodynamic injection, F.VIII-expressing plasmids have also been targeted to specific cell types using nanocapsules. Targeting SBmediated transduction of F.VIII to liver sinusoidal endothelial cells (LSECs) of adult HA mice using hyaluronon nanocapsules induced sustained correction of clotting function (337). An alternative approach for in vivo gene therapy involves the oral delivery of plasmid DNA encapsulated in chitosan nanoparticles (205). This approach provides phenotypic correction of hemophilic mice, and repeated delivery provides sustained correction in the absence of an immune response to F.VIII $(338,339)$. In both of these nanoparticle mediated approaches, mice were not challenged with exogenous F.VIII to verify if they were tolerized to F. VIII, or if they merely failed to mount an immune response to the endogenously-produced protein.

Nonviral gene transfer has also been employed ex vivo for the treatment of hemophilia A. In human patients, this ex vivo approach was used to transduce autologous dermal fibroblasts and select for F.VIII-producing cells (340). Delivery of these genetically modified fibroblasts into hemophilic patients provided a slight decrease in the number of bleeding events, and no inhibitor formation was detected. However, these clinical improvements only lasted for about 10 months, likely due to loss of the transduced cells. Given these promising results, subsequent studies have focused on finding a superior cell type for ex vivo transduction, both in terms of secretion capacity as well as persistence. In particular, blood outgrowth endothelial cells (BOECs) have shown promise for this approach. These cells, derived from circulating endothelial cells in peripheral blood, display many of the characteristics of endothelial cells, including vWF expression (341). Additionally, BOECs grow extremely well in culture; after 65 days, they can be expanded from about 20 cells to $10^{19}$ cells (341). Following gene transfer, selection, and injection into mice, genetically modified BOECs induced therapeutic or even supraphysiologic circulating levels of hF.VIII, depending on the cell dose (342). These cells maintained an endothelial phenotype and accumulated primarily in spleen and bone marrow. Further studies have also achieved persistent seeding of liver and lung in addition to the spleen and bone marrow (343). Other approaches have involved nonviral modification of hepatocytes and embryonic stem cells 
(344, 345). F.VIII-expressing endothelial cells derived from iPS cells have also shown promise for the treatment of hemophilia A (346). iPS cells have also been modified with human artificial chromosomes (HACs), constructs that mimic a human chromosome. HACs are maintained separately from the host genome (minimizing the risk of insertional mutagenesis), persist through cell divisions due to their ability to bind centrosomal proteins, and allow for delivery of large constructs that can mimic physiological gene regulation (347-350). Megakaryocytes/platelets derived from iPS cells have been generated that produce F.VIII following transduction with a HAC, though their in vivo efficacy has not yet been demonstrated (351).

\subsection{Optimization of factor VIII}

Finally, the optimization of the F.VIII transgene represents a vector-agnostic approach to improving gene therapy. As previously mentioned, codon optimization of F.VIII has been shown to enhance transgene expression (283). However, the inefficient secretion of F.VIII provides additional routes for transgene optimization. Interestingly, porcine F.VIII is secreted by cells more efficiently than human F.VIII (352-354). HSCs expressing porcine F.VIII are able to correct the bleeding phenotype following implantation into hemophilic mice $(303,304,355)$. Further studies have incorporated porcine sequences into hF.VIII to enhance secretion of the clotting factor while still maintaining a largely human protein; this hybrid protein can also mediate clotting activity in vivo following implantation of transduced HSCs (356-358). Another interesting aspect of porcine F.VIII is its differential immunogenicity relative to hF.VIII. Although the magnitude of the response to both proteins is largely comparable, antibody responses preferentially target different epitopes in porcine or human F.VIII, and some reports have suggested that porcine F.VIII may be able to bypass inhibitors directed against hF.VIII (359-362). Similarly, canine F.VIII is more stable and exhibits greater specific activity than hF.VIII (363). Incorporation of a point mutation (R1645H) from canine F.VIII into hF.VIII conferred many of these properties to the new transgene, and expression of this altered F.VIII via an AAV vector was more effective and comparably immunogenic to BDD-F.VIII (364). Other strategies for enhancing secretion include the incorporation of a fragment of the light chain into the heavy chain (whose secretion is the rate limiting step) or the use of chemical chaperones $(365,366)$.

Alternatively, one can simply bypass F.VIII altogether. Expression of activated factor VIIa in hepatocytes or platelets has been shown to provide bleeding correction in the absence of thrombotic events $(367,368)$. F.IX variants that do not require F.VIII, or an antibody that mimics F.VIII's role in the intrinsic factor Xase by bringing F.IX and F.X into close proximity are also able to provide therapeutic benefit $(369,370)$. By completely avoiding F.VIII, these strategies sidestep complications posed by the immune system. In addition to preventing the risks associated with a de novo inhibitor response to the gene therapy, they would also be appropriate for use in patients with preexisting inhibitors without being concerned with tolerance induction. However, there are also potential risks for thrombosis when bypassing the natural regulation of the coagulation cascade, and these mechanisms will likely need thorough safety studies before being applied in the clinic. 


\section{CONCLUSION}

Clearly, the field of gene therapy for hemophilia is being thoroughly explored. Given its recent clinical success, AAV-mediated hepatic gene transfer is likely to be the primary direction going forward for hemophilia B. However, there are still a number of problems that limit the broad applicability of the current approach, particularly the current immunosuppressive regimen and pre-existing neutralizing antibodies. Perhaps these barriers to transduction will be fixed with more specific therapies or a combinatorial approach of several techniques to bypass NAB. Alternatively, a different approach that does not have to deal with these anti-vector immune responses, such as an ex vivo or nonviral technique, might become a more effective way to administer gene therapy to the broadest base of patients. For hemophilia A, while AAV-mediated gene therapy has potential, a number of limitations reduce its desirability, including packaging capacity and inefficient expression. While a number of transgene modifications have increased the expression levels, the vector doses required to achieve corrective F.VIII expression remain significantly higher than with F.IX. These expression limitations lead to further concerns about immune responses both to the capsid and, if expression levels are not sufficient, the transgene. As such, ex vivo gene transfer may be more effective for hemophilia A due to its ability to enhance expression through cellular division. Specifically, gene transfer to platelets is a promising example of this technique. This approach appears to bypass barriers posed by the immune system, as the local expression and release of F.VIII can correct the bleeding phenotype in the presence of inhibitors. This technique, too, has its drawbacks, particularly in terms of delivery. Current techniques involve the use of integrating viral vectors, for which concerns about oncogenicity have not been fully addressed. Thus, while a number of promising approaches for gene therapy for hemophilia have been elucidated, there are clearly numerous problems that still need to be addressed to develop approved gene therapies for both hemophilia A and $\mathrm{B}$ for use in humans.

\section{ACKNOWLEDGEMENTS}

This manuscript has been supported by NIH grants P01 HL078810, R01 HL097088, R01 AI51390, and R01 HL109442. GLR was supported by a Dean's Fellowship from the University of Florida College of Medicine.

\section{Abbreviations}

$\begin{array}{ll}\text { F.VIII } & \text { factor VIII } \\ \text { F.IX } & \text { factor IX } \\ \text { F.VII } & \text { factor VII } \\ \text { F.X } & \text { factor X } \\ \text { ITI } & \text { immune tolerance induction } \\ \text { AAV } & \text { adeno-associated virus } \\ \text { ITR } & \text { inverted terminal repeat } \\ \text { Treg } & \text { regulatory T cell }\end{array}$




\begin{tabular}{|c|c|}
\hline scAAV & self-complementary AAV \\
\hline SsAAV & single-stranded AAV \\
\hline TLR9 & toll-like receptor 9 \\
\hline CTL & cytotoxic T lymphocyte \\
\hline МHC & major histocompatibility complex \\
\hline NAB & neutralizing antibody \\
\hline MMLV & Moloney murine leukemia virus \\
\hline $\mathbf{L V}$ & lentivirus \\
\hline HIV & human immunodeficiency virus \\
\hline VSV & vesicular stomatitis virus \\
\hline LCMV & lymphocytic choriomeningitis virus \\
\hline SIN-LV & self-inactivating lentivirus \\
\hline HSC & hemaptopoietic stem cell \\
\hline mADSC & murine adipose tissue-derived stem/stromal cells \\
\hline miR-142 & microRNA 142 \\
\hline IFN & interferon \\
\hline TLR7 & toll-like receptor 7 \\
\hline cGAS & cyclic GMP-AMP synthetase \\
\hline IDLV & integrase-defective lentivirus \\
\hline SB & Sleeping Beauty \\
\hline ZFN & zinc-finger nuclease \\
\hline TALEN & transcription activator-like effector nuclease \\
\hline CRISPR & clustered regularly interspaced short palindromic repeats \\
\hline Cas & CRISPR-associated systems \\
\hline BiP & immunoglobulin binding protein \\
\hline vWF & von Willebrand factor \\
\hline LSEC & liver sinusoidal endothelial cell \\
\hline i.v. & intravenous \\
\hline BDD-F.VIII & B-domain-deleted factor VIII \\
\hline FIV & feline immunodeficiency virus \\
\hline BU & Bethesda unit \\
\hline MSC & mesenchymal stem cell \\
\hline
\end{tabular}




$\begin{array}{ll}\text { IDO } & \text { indoleamine 2,3-dioxygenase } \\ \text { BOEC } & \text { blood outgrowth endothelial cell } \\ \text { iPS } & \text { induced pluripotent stem cell } \\ \text { HAC } & \text { human artificial chromosome }\end{array}$

\section{REFERENCES}

1. Manco-Johnson MJ, Abshire TC, Shapiro AD, Riske B, Hacker MR, Kilcoyne R, Ingram JD, Manco-Johnson ML, Funk S, Jacobson L, Valentino LA, Hoots WK, Buchanan GR, DiMichele D, Recht M, Brown D, Leissinger C, Bleak S, Cohen A, Mathew P, Matsunaga A, Medeiros D, Nugent D, Thomas GA, Thompson AA, McRedmond K, Soucie JM, Austin H, Evatt BL. Prophylaxis versus episodic treatment to prevent joint disease in boys with severe hemophilia. N Engl J Med. 2007; 357(6):535-44. [PubMed: 17687129]

2. Ragni MV. The old and new: PCCs, VIIa, and long-lasting clotting factors for hemophilia and other bleeding disorders. Hematology Am Soc Hematol Educ Program. 2013; 2013:44-51. [PubMed: 24319161]

3. Cao O, Hoffman BE, Moghimi B, Nayak S, Cooper M, Zhou S, Ertl HC, High KA, Herzog RW. Impact of the underlying mutation and the route of vector administration on immune responses to factor IX in gene therapy for hemophilia B. Mol Ther. 2009; 17(10):1733-42. [PubMed: 19603001]

4. Markusic DM, Hoffman BE, Perrin GQ, Nayak S, Wang X, Loduca PA, High KA, Herzog RW. Effective gene therapy for haemophilic mice with pathogenic factor IX antibodies. EMBO Mol Med. 2013

5. Chitlur M, Warrier I, Rajpurkar M, Lusher JM. Inhibitors in factor IX deficiency a report of the ISTH-SSC international FIX inhibitor registry (1997-2006). Haemophilia. 2009; 15(5):1027-31. [PubMed: 19515028]

6. Gouw SC, van den Berg HM, Oldenburg J, Astermark J, de Groot PG, Margaglione M, Thompson AR, van Heerde W, Boekhorst J, Miller CH, le Cessie S, van der Bom JG. F8 gene mutation type and inhibitor development in patients with severe hemophilia A: systematic review and metaanalysis. Blood. 2012; 119(12):2922-34. [PubMed: 22282501]

7. Halimeh S, Bidlingmaier C, Heller C, Gutsche S, Holzhauer S, Kenet G, Kurnik K, Manner D, Iorio A, Nowak-Gottl U. Risk factors for high-titer inhibitor development in children with hemophilia A: results of a cohort study. Biomed Res Int. 2013; 2013:901975. [PubMed: 24199202]

8. Mariani G, Siragusa S, Kroner BL. Immune tolerance induction in hemophilia A: a review. Semin Thromb Hemost. 2003; 29(1):69-76. [PubMed: 12640568]

9. Hay CR, DiMichele DM. The principal results of the International Immune Tolerance Study: a randomized dose comparison. Blood. 2012; 119(6):1335-44. [PubMed: 22101900]

10. Markusic DM, Herzog RW. Liver-Directed Adeno-Associated Viral Gene Therapy for Hemophilia. J Genet Syndr Gene Ther. 2012; 1:1-9. [PubMed: 23565343]

11. High KH, Nathwani A, Spencer T, Lillicrap D. Current status of haemophilia gene therapy. Haemophilia. 2014; 20(Suppl 4):43-9. [PubMed: 24762274]

12. Gomez-Vargas A, Hortelano G. Nonviral gene therapy approaches to hemophilia. Semin Thromb Hemost. 2004; 30(2):197-204. [PubMed: 15118931]

13. Brown BD, Sitia G, Annoni A, Hauben E, Sergi LS, Zingale A, Roncarolo MG, Guidotti LG, Naldini L. In vivo administration of lentiviral vectors triggers a type I interferon response that restricts hepatocyte gene transfer and promotes vector clearance. Blood. 2007; 109(7):2797-805. [PubMed: 17170119]

14. Agudo J, Ruzo A, Kitur K, Sachidanandam R, Blander JM, Brown BD. A TLR and non-TLR mediated innate response to lentiviruses restricts hepatocyte entry and can be ameliorated by pharmacological blockade. Mol Ther. 2012; 20(12):2257-67. [PubMed: 22871668] 
15. Mingozzi F, High KA. Immune responses to AAV vectors: overcoming barriers to successful gene therapy. Blood. 2013; 122(1):23-36. [PubMed: 23596044]

16. Miao CH. Advances in Overcoming Immune Responses following Hemophilia Gene Therapy. J Genet Syndr Gene Ther. 2011:S1. [PubMed: 23565342]

17. Sack BK, Herzog RW, Terhorst C, Markusic DM. Development of gene transfer for induction of antigen-specific tolerance. Mol Ther Methods Clin Dev. 2014:1. [PubMed: 26015941]

18. Mingozzi F, High KA. Therapeutic in vivo gene transfer for genetic disease using AAV: progress and challenges. Nat Rev Genet. 2011; 12(5):341-55. [PubMed: 21499295]

19. Arruda VR, Hagstrom JN, Deitch J, Heiman-Patterson T, Camire RM, Chu K, Fields PA, Herzog RW, Couto LB, Larson PJ, High KA. Posttranslational modifications of recombinant myotubesynthesized human factor IX. Blood. 2001; 97(1):130-8. [PubMed: 11133752]

20. Nakai H, Yant SR, Storm TA, Fuess S, Meuse L, Kay MA. Extrachromosomal recombinant adenoassociated virus vector genomes are primarily responsible for stable liver transduction in vivo. $\mathbf{J}$ Virol. 2001; 75(15):6969-76. [PubMed: 11435577]

21. Kaeppel C, Beattie SG, Fronza R, van Logtenstein R, Salmon F, Schmidt S, Wolf S, Nowrouzi A, Glimm H, von Kalle C, Petry H, Gaudet D, Schmidt M. A largely random AAV integration profile after LPLD gene therapy. Nat Med. 2013; 19(7):889-91. [PubMed: 23770691]

22. Zaiss AK, Liu Q, Bowen GP, Wong NC, Bartlett JS, Muruve DA. Differential activation of innate immune responses by adenovirus and adeno-associated virus vectors. J Virol. 2002; 76(9):4580 90. [PubMed: 11932423]

23. Zaiss AK, Muruve DA. Immune responses to adeno-associated virus vectors. Curr Gene Ther. 2005; 5(3):323-31. [PubMed: 15975009]

24. Wu Z, Asokan A, Samulski RJ. Adeno-associated virus serotypes: vector toolkit for human gene therapy. Mol Ther. 2006; 14(3):316-27. [PubMed: 16824801]

25. Herzog RW, Hagstrom JN, Kung SH, Tai SJ, Wilson JM, Fisher KJ, High KA. Stable gene transfer and expression of human blood coagulation factor IX after intramuscular injection of recombinant adeno-associated virus. Proc Natl Acad Sci U S A. 1997; 94(11):5804-9. [PubMed: 9159155]

26. Herzog RW, Yang EY, Couto LB, Hagstrom JN, Elwell D, Fields PA, Burton M, Bellinger DA, Read MS, Brinkhous KM, Podsakoff GM, Nichols TC, Kurtzman GJ, High KA. Long-term correction of canine hemophilia B by gene transfer of blood coagulation factor IX mediated by adeno-associated viral vector. Nat Med. 1999; 5(1):56-63. [PubMed: 9883840]

27. Fields PA, Kowalczyk DW, Arruda VR, Armstrong E, McCleland ML, Hagstrom JN, Pasi KJ, Ertl HC, Herzog RW, High KA. Role of vector in activation of T cell subsets in immune responses against the secreted transgene product factor IX. Mol Ther. 2000; 1(3):225-35. [PubMed: 10933938]

28. Hagstrom JN, Couto LB, Scallan C, Burton M, McCleland ML, Fields PA, Arruda VR, Herzog RW, High KA. Improved muscle-derived expression of human coagulation factor IX from a skeletal actin/CMV hybrid enhancer/promoter. Blood. 2000; 95(8):2536-42. [PubMed: 10753832]

29. Kay MA, Manno CS, Ragni MV, Larson PJ, Couto LB, McClelland A, Glader B, Chew AJ, Tai SJ, Herzog RW, Arruda V, Johnson F, Scallan C, Skarsgard E, Flake AW, High KA. Evidence for gene transfer and expression of factor IX in haemophilia B patients treated with an AAV vector. Nat Genet. 2000; 24(3):257-61. [PubMed: 10700178]

30. Manno CS, Chew AJ, Hutchison S, Larson PJ, Herzog RW, Arruda VR, Tai SJ, Ragni MV, Thompson A, Ozelo M, Couto LB, Leonard DG, Johnson FA, McClelland A, Scallan C, Skarsgard E, Flake AW, Kay MA, High KA, Glader B. AAV-mediated factor IX gene transfer to skeletal muscle in patients with severe hemophilia B. Blood. 2003; 101(8):2963-72. [PubMed: 12515715]

31. Gao GP, Alvira MR, Wang L, Calcedo R, Johnston J, Wilson JM. Novel adeno-associated viruses from rhesus monkeys as vectors for human gene therapy. Proc Natl Acad Sci U S A. 2002; 99(18): 11854-9. [PubMed: 12192090]

32. Flotte TR, Trapnell BC, Humphries M, Carey B, Calcedo R, Rouhani F, Campbell-Thompson M, Yachnis AT, Sandhaus RA, McElvaney NG, Mueller C, Messina LM, Wilson JM, Brantly M, Knop DR, Ye GJ, Chulay JD. Phase 2 clinical trial of a recombinant adeno-associated viral vector expressing alpha1-antitrypsin: interim results. Hum Gene Ther. 2011; 22(10):1239-47. [PubMed: 21609134] 
33. Mueller C, Chulay JD, Trapnell BC, Humphries M, Carey B, Sandhaus RA, McElvaney NG, Messina L, Tang Q, Rouhani FN, Campbell-Thompson M, Fu AD, Yachnis A, Knop DR, Ye GJ, Brantly M, Calcedo R, Somanathan S, Richman LP, Vonderheide RH, Hulme MA, Brusko TM, Wilson JM, Flotte TR. Human Treg responses allow sustained recombinant adeno-associated virus-mediated transgene expression. J Clin Invest. 2013; 123(12):5310-8. [PubMed: 24231351]

34. Burnett JR, Hooper AJ. Alipogene tiparvovec, an adeno-associated virus encoding the Ser(447)X variant of the human lipoprotein lipase gene for the treatment of patients with lipoprotein lipase deficiency. Curr Opin Mol Ther. 2009; 11(6):681-91. [PubMed: 20072945]

35. Fields PA, Arruda VR, Armstrong E, Chu K, Mingozzi F, Hagstrom JN, Herzog RW, High KA. Risk and prevention of anti-factor IX formation in AAV-mediated gene transfer in the context of a large deletion of F9. Mol Ther. 2001; 4(3):201-10. [PubMed: 11545610]

36. Wang L, Cao O, Swalm B, Dobrzynski E, Mingozzi F, Herzog RW. Major role of local immune responses in antibody formation to factor IX in AAV gene transfer. Gene Ther. 2005; 12(19): 1453-64. [PubMed: 15889137]

37. Wang L, Dobrzynski E, Schlachterman A, Cao O, Herzog RW. Systemic protein delivery by muscle-gene transfer is limited by a local immune response. Blood. 2005; 105(11):4226-34. [PubMed: 15713796]

38. Herzog RW, Fields PA, Arruda VR, Brubaker JO, Armstrong E, McClintock D, Bellinger DA, Couto LB, Nichols TC, High KA. Influence of vector dose on factor IX-specific T and B cell responses in muscle-directed gene therapy. Hum Gene Ther. 2002; 13(11):1281-91. [PubMed: 12162811]

39. Herzog RW, Mount JD, Arruda VR, High KA, Lothrop CD Jr. Muscle-directed gene transfer and transient immune suppression result in sustained partial correction of canine hemophilia $\mathrm{B}$ caused by a null mutation. Mol Ther. 2001; 4(3):192-200. [PubMed: 11545609]

40. Buchlis G, Podsakoff GM, Radu A, Hawk SM, Flake AW, Mingozzi F, High KA. Factor IX expression in skeletal muscle of a severe hemophilia B patient 10 years after AAV-mediated gene transfer. Blood. 2012; 119(13):3038-41. [PubMed: 22271447]

41. Arruda VR, Stedman HH, Haurigot V, Buchlis G, Baila S, Favaro P, Chen Y, Franck HG, Zhou S, Wright JF, Couto LB, Jiang H, Pierce GF, Bellinger DA, Mingozzi F, Nichols TC, High KA. Peripheral transvenular delivery of adeno-associated viral vectors to skeletal muscle as a novel therapy for hemophilia B. Blood. 2010; 115(23):4678-88. [PubMed: 20335222]

42. Finn JD, Nichols TC, Svoronos N, Merricks EP, Bellenger DA, Zhou S, Simioni P, High KA, Arruda VR. The efficacy and the risk of immunogenicity of FIX Padua (R338L) in hemophilia B dogs treated by AAV muscle gene therapy. Blood. 2012; 120(23):4521-3. [PubMed: 22919027]

43. Mingozzi F, Liu YL, Dobrzynski E, Kaufhold A, Liu JH, Wang Y, Arruda VR, High KA, Herzog RW. Induction of immune tolerance to coagulation factor IX antigen by in vivo hepatic gene transfer. J Clin Invest. 2003; 111(9):1347-56. [PubMed: 12727926]

44. Dobrzynski E, Fitzgerald JC, Cao O, Mingozzi F, Wang L, Herzog RW. Prevention of cytotoxic T lymphocyte responses to factor IX-expressing hepatocytes by gene transfer-induced regulatory $\mathrm{T}$ cells. Proc Natl Acad Sci U S A. 2006; 103(12):4592-7. [PubMed: 16537361]

45. Cao O, Dobrzynski E, Wang L, Nayak S, Mingle B, Terhorst C, Herzog RW. Induction and role of regulatory $\mathrm{CD} 4+\mathrm{CD} 25+\mathrm{T}$ cells in tolerance to the transgene product following hepatic in vivo gene transfer. Blood. 2007; 110(4):1132-40. [PubMed: 17438084]

46. Cao O, Loduca PA, Herzog RW. Role of regulatory T cells in tolerance to coagulation factors. J Thromb Haemost. 2009; 7(Suppl 1):88-91. [PubMed: 19630776]

47. LoDuca PA, Hoffman BE, Herzog RW. Hepatic Gene Transfer as a Means of Tolerance Induction to Transgene Products. Current gene therapy. 2009; 9(2):104-114. [PubMed: 19355868]

48. Caridade M, Graca L, Ribeiro RM. Mechanisms Underlying CD4+ Treg Immune Regulation in the Adult: From Experiments to Models. Front Immunol. 2013; 4:378. [PubMed: 24302924]

49. Martino AT, Nayak S, Hoffman BE, Cooper M, Liao G, Markusic DM, Byrne BJ, Terhorst C, Herzog RW. Tolerance induction to cytoplasmic beta-galactosidase by hepatic AAV gene transfer: implications for antigen presentation and immunotoxicity. PLoS One. 2009; 4(8):e6376. [PubMed: 19652717] 
50. Hoffman BE, Martino AT, Sack BK, Cao O, Liao G, Terhorst C, Herzog RW. Nonredundant roles of IL-10 and TGF-beta in suppression of immune responses to hepatic AAV-factor IX gene transfer. Mol Ther. 2011; 19(7):1263-72. [PubMed: 21386826]

51. Reipert BM, Allacher P, Hausl C, Pordes AG, Ahmad RU, Lang I, Ilas J, Windyga J, Klukowska A, Muchitsch EM, Schwarz HP. Modulation of factor VIII-specific memory B cells. Haemophilia. 2010; 16(102):25-34. [PubMed: 20536983]

52. Manno CS, Pierce GF, Arruda VR, Glader B, Ragni M, Rasko JJ, Ozelo MC, Hoots K, Blatt P, Konkle B, Dake M, Kaye R, Razavi M, Zajko A, Zehnder J, Rustagi PK, Nakai H, Chew A, Leonard D, Wright JF, Lessard RR, Sommer JM, Tigges M, Sabatino D, Luk A, Jiang H, Mingozzi F, Couto L, Ertl HC, High KA, Kay MA. Successful transduction of liver in hemophilia by AAV-Factor IX and limitations imposed by the host immune response. Nat Med. 2006; 12(3): 342-7. [PubMed: 16474400]

53. Nathwani AC, Tuddenham EG, Rangarajan S, Rosales C, McIntosh J, Linch DC, Chowdary P, Riddell A, Pie AJ, Harrington C, O'Beirne J, Smith K, Pasi J, Glader B, Rustagi P, Ng CY, Kay MA, Zhou J, Spence Y, Morton CL, Allay J, Coleman J, Sleep S, Cunningham JM, Srivastava D, Basner-Tschakarjan E, Mingozzi F, High KA, Gray JT, Reiss UM, Nienhuis AW, Davidoff AM. Adenovirus-associated virus vector-mediated gene transfer in hemophilia B. N Engl J Med. 2011; 365(25):2357-65. [PubMed: 22149959]

54. Herzog RW. Immune responses to AAV capsid: are mice not humans after all? Mol Ther. 2007; 15(4):649-50. [PubMed: 17372595]

55. Mingozzi F, High KA. Immune responses to AAV in clinical trials. Curr Gene Ther. 2007; 7(5): 316-24. [PubMed: 17979678]

56. Mingozzi F, Maus MV, Hui DJ, Sabatino DE, Murphy SL, Rasko JE, Ragni MV, Manno CS, Sommer J, Jiang H, Pierce GF, Ertl HC, High KA. CD8(+) T-cell responses to adeno-associated virus capsid in humans. Nat Med. 2007; 13(4):419-22. [PubMed: 17369837]

57. Cooper M, Nayak S, Hoffman BE, Terhorst C, Cao O, Herzog RW. Improved induction of immune tolerance to factor IX by hepatic AAV-8 gene transfer. Hum Gene Ther. 2009; 20(7):76776. [PubMed: 19309290]

58. Calcedo R, Vandenberghe LH, Gao G, Lin J, Wilson JM. Worldwide epidemiology of neutralizing antibodies to adeno-associated viruses. J Infect Dis. 2009; 199(3):381-90. [PubMed: 19133809]

59. Boutin S, Monteilhet V, Veron P, Leborgne C, Benveniste O, Montus MF, Masurier C. Prevalence of serum IgG and neutralizing factors against adeno-associated virus (AAV) types 1, 2, 5, 6, 8, and 9 in the healthy population: implications for gene therapy using AAV vectors. Hum Gene Ther. 2010; 21(6):704-12. [PubMed: 20095819]

60. McCarty DM, Monahan PE, Samulski RJ. Self-complementary recombinant adeno-associated virus (scAAV) vectors promote efficient transduction independently of DNA synthesis. Gene Ther. 2001; 8(16):1248-54. [PubMed: 11509958]

61. Ferrari FK, Samulski T, Shenk T, Samulski RJ. Second-strand synthesis is a rate-limiting step for efficient transduction by recombinant adeno-associated virus vectors. J Virol. 1996; 70(5):322734. [PubMed: 8627803]

62. McCarty DM, Fu H, Monahan PE, Toulson CE, Naik P, Samulski RJ. Adeno-associated virus terminal repeat (TR) mutant generates self-complementary vectors to overcome the rate-limiting step to transduction in vivo. Gene Ther. 2003; 10(26):2112-8. [PubMed: 14625565]

63. Wu Z, Sun J, Zhang T, Yin C, Yin F, Van Dyke T, Samulski RJ, Monahan PE. Optimization of self-complementary AAV vectors for liver-directed expression results in sustained correction of hemophilia B at low vector dose. Mol Ther. 2008; 16(2):280-9. [PubMed: 18059373]

64. Nathwani AC, Rosales C, McIntosh J, Rastegarlari G, Nathwani D, Raj D, Nawathe S, Waddington SN, Bronson R, Jackson S, Donahue RE, High KA, Mingozzi F, Ng CY, Zhou J, Spence Y, McCarville MB, Valentine M, Allay J, Coleman J, Sleep S, Gray JT, Nienhuis AW, Davidoff AM. Long-term safety and efficacy following systemic administration of a selfcomplementary AAV vector encoding human FIX pseudotyped with serotype 5 and 8 capsid proteins. Mol Ther. 2011; 19(5):876-85. [PubMed: 21245849]

65. Raj D, Davidoff AM, Nathwani AC. Self-complementary adeno-associated viral vectors for gene therapy of hemophilia B: progress and challenges. Expert Rev Hematol. 2011; 4(5):539-49. [PubMed: 21939421] 
66. Zhu J, Huang X, Yang Y. The TLR9-MyD88 pathway is critical for adaptive immune responses to adeno-associated virus gene therapy vectors in mice. J Clin Invest. 2009; 119(8):2388-98. [PubMed: 19587448]

67. Martino AT, Suzuki M, Markusic DM, Zolotukhin I, Ryals RC, Moghimi B, Ertl HC, Muruve DA, Lee B, Herzog RW. The genome of self-complementary adeno-associated viral vectors increases Toll-like receptor 9-dependent innate immune responses in the liver. Blood. 2011; 117(24):645968. [PubMed: 21474674]

68. Wu T, Topfer K, Lin SW, Li H, Bian A, Zhou XY, High KA, Ertl HC. Self-complementary AAVs induce more potent transgene product-specific immune responses compared to a single-stranded genome. Mol Ther. 2012; 20(3):572-9. [PubMed: 22186792]

69. Rogers GL, Martino AT, Aslanidi GV, Jayandharan GR, Srivastava A, Herzog RW. Innate Immune Responses to AAV Vectors. Front Microbiol. 2011; 2:194. [PubMed: 21954398]

70. Faust SM, Bell P, Cutler BJ, Ashley SN, Zhu Y, Rabinowitz JE, Wilson JM. CpG-depleted adenoassociated virus vectors evade immune detection. J Clin Invest. 2013; 123(7):2994-3001. [PubMed: 23778142]

71. Rogers GL, Martino AT, Zolotukhin I, Ertl HC, Herzog RW. Role of the vector genome and underlying factor IX mutation in immune responses to AAV gene therapy for hemophilia B. J Transl Med. 2014; 12(1):25. [PubMed: 24460861]

72. Suzuki M, Bertin TK, Rogers GL, Cela RG, Zolotukhin I, Palmer DJ, Ng P, Herzog RW, Lee B. Differential type I interferon-dependent transgene silencing of helper-dependent adenoviral vs. adeno-associated viral vectors in vivo. Mol Ther. 2013; 21(4):796-805. [PubMed: 23319058]

73. Jayandharan GR, Aslanidi G, Martino AT, Jahn SC, Perrin GQ, Herzog RW, Srivastava A. Activation of the NF-kappaB pathway by adeno-associated virus (AAV) vectors and its implications in immune response and gene therapy. Proc Natl Acad Sci U S A. 2011; 108(9): 3743-8. [PubMed: 21321191]

74. Zhong L, Zhao W, Wu J, Li B, Zolotukhin S, Govindasamy L, Agbandje-McKenna M, Srivastava A. A dual role of EGFR protein tyrosine kinase signaling in ubiquitination of AAV2 capsids and viral second-strand DNA synthesis. Mol Ther. 2007; 15(7):1323-30. [PubMed: 17440440]

75. Zhong L, Li B, Jayandharan G, Mah CS, Govindasamy L, Agbandje-McKenna M, Herzog RW, Weigel-Van Aken KA, Hobbs JA, Zolotukhin S, Muzyczka N, Srivastava A. Tyrosinephosphorylation of AAV2 vectors and its consequences on viral intracellular trafficking and transgene expression. Virology. 2008; 381(2):194-202. [PubMed: 18834608]

76. Li C, He Y, Nicolson S, Hirsch M, Weinberg MS, Zhang P, Kafri T, Samulski RJ. Adenoassociated virus capsid antigen presentation is dependent on endosomal escape. J Clin Invest. 2013; 123(3):1390-401. [PubMed: 23454772]

77. Zhong L, Li B, Mah CS, Govindasamy L, Agbandje-McKenna M, Cooper M, Herzog RW, Zolotukhin I, Warrington KH Jr. Weigel-Van Aken KA, Hobbs JA, Zolotukhin S, Muzyczka N, Srivastava A. Next generation of adeno-associated virus 2 vectors: point mutations in tyrosines lead to high-efficiency transduction at lower doses. Proc Natl Acad Sci U S A. 2008; 105(22): 7827-32. [PubMed: 18511559]

78. Markusic DM, Herzog RW, Aslanidi GV, Hoffman BE, Li B, Li M, Jayandharan GR, Ling C, Zolotukhin I, Ma W, Zolotukhin S, Srivastava A, Zhong L. High-efficiency transduction and correction of murine hemophilia B using AAV2 vectors devoid of multiple surface-exposed tyrosines. Mol Ther. 2010; 18(12):2048-56. [PubMed: 20736929]

79. Martino AT, Basner-Tschakarjan E, Markusic DM, Finn JD, Hinderer C, Zhou S, Ostrov DA, Srivastava A, Ertl HC, Terhorst C, High KA, Mingozzi F, Herzog RW. Engineered AAV vector minimizes in vivo targeting of transduced hepatocytes by capsid-specific CD8+ T cells. Blood. 2013

80. Wu TL, Li H, Faust SM, Chi E, Zhou S, Wright F, High KA, Ertl HC. CD8(+) T Cell Recognition of Epitopes Within the Capsid of Adeno-associated Virus 8-based Gene Transfer Vectors Depends on Vectors' Genome. Mol Ther. 2014; 22(1):42-51. [PubMed: 24077034]

81. Masat E, Pavani G, Mingozzi F. Humoral immunity to AAV vectors in gene therapy: challenges and potential solutions. Discov Med. 2013; 15(85):379-89. [PubMed: 23819952] 
82. Scallan CD, Jiang H, Liu T, Patarroyo-White S, Sommer JM, Zhou S, Couto LB, Pierce GF. Human immunoglobulin inhibits liver transduction by AAV vectors at low AAV2 neutralizing titers in SCID mice. Blood. 2006; 107(5):1810-7. [PubMed: 16249376]

83. Jiang H, Couto LB, Patarroyo-White S, Liu T, Nagy D, Vargas JA, Zhou S, Scallan CD, Sommer J, Vijay S, Mingozzi F, High KA, Pierce GF. Effects of transient immunosuppression on adenoassociated, virus-mediated, liver-directed gene transfer in rhesus macaques and implications for human gene therapy. Blood. 2006; 108(10):3321-8. [PubMed: 16868252]

84. Wang L, Calcedo R, Bell P, Lin J, Grant RL, Siegel DL, Wilson JM. Impact of pre-existing immunity on gene transfer to nonhuman primate liver with adeno-associated virus 8 vectors. Hum Gene Ther. 2011; 22(11):1389-401. [PubMed: 21476868]

85. Bowles DE, McPhee SW, Li C, Gray SJ, Samulski JJ, Camp AS, Li J, Wang B, Monahan PE, Rabinowitz JE, Grieger JC, Govindasamy L, Agbandje-McKenna M, Xiao X, Samulski RJ. Phase 1 gene therapy for Duchenne muscular dystrophy using a translational optimized AAV vector. Mol Ther. 2012; 20(2):443-55. [PubMed: 22068425]

86. Bartel MA, Weinstein JR, Schaffer DV. Directed evolution of novel adeno-associated viruses for therapeutic gene delivery. Gene Ther. 2012; 19(6):694-700. [PubMed: 22402323]

87. Monteilhet V, Saheb S, Boutin S, Leborgne C, Veron P, Montus MF, Moullier P, Benveniste O, Masurier C. A 10 patient case report on the impact of plasmapheresis upon neutralizing factors against adeno-associated virus (AAV) types 1, 2, 6, and 8. Mol Ther. 2011; 19(11):2084-91. [PubMed: 21629225]

88. Hurlbut GD, Ziegler RJ, Nietupski JB, Foley JW, Woodworth LA, Meyers E, Bercury SD, Pande NN, Souza DW, Bree MP, Lukason MJ, Marshall J, Cheng SH, Scheule RK. Preexisting immunity and low expression in primates highlight translational challenges for liver-directed AAV8mediated gene therapy. Mol Ther. 2010; 18(11):1983-94. [PubMed: 20736932]

89. Mimuro J, Mizukami H, Hishikawa S, Ikemoto T, Ishiwata A, Sakata A, Ohmori T, Madoiwa S, Ono F, Ozawa K, Sakata Y. Minimizing the inhibitory effect of neutralizing antibody for efficient gene expression in the liver with adeno-associated virus 8 vectors. Mol Ther. 2013; 21(2):318-23. [PubMed: 23247100]

90. Mingozzi F, Chen Y, Edmonson SC, Zhou S, Thurlings RM, Tak PP, High KA, Vervoordeldonk MJ. Prevalence and pharmacological modulation of humoral immunity to AAV vectors in gene transfer to synovial tissue. Gene Ther. 2013; 20(4):417-24. [PubMed: 22786533]

91. Hoyer BF, Manz RA, Radbruch A, Hiepe F. Long-lived plasma cells and their contribution to autoimmunity. Ann N Y Acad Sci. 2005; 1050:124-33. [PubMed: 16014527]

92. Mingozzi F, Chen Y, Murphy SL, Edmonson SC, Tai A, Price SD, Metzger ME, Zhou S, Wright JF, Donahue RE, Dunbar CE, High KA. Pharmacological modulation of humoral immunity in a nonhuman primate model of AAV gene transfer for hemophilia B. Mol Ther. 2012; 20(7):1410-6. [PubMed: 22565846]

93. McIntosh JH, Cochrane M, Cobbold S, Waldmann H, Nathwani SA, Davidoff AM, Nathwani AC. Successful attenuation of humoral immunity to viral capsid and transgenic protein following AAV-mediated gene transfer with a non-depleting CD4 antibody and cyclosporine. Gene Ther. 2012; 19(1):78-85. [PubMed: 21716299]

94. Mingozzi F, Anguela XM, Pavani G, Chen Y, Davidson RJ, Hui DJ, Yazicioglu M, Elkouby L, Hinderer CJ, Faella A, Howard C, Tai A, Podsakoff GM, Zhou S, Basner-Tschakarjan E, Wright JF, High KA. Overcoming preexisting humoral immunity to AAV using capsid decoys. Sci Transl Med. 2013; 5(194):194ra92.

95. Wright JF. AAV Empty Capsids: For Better or for Worse? Mol Ther. 2014; 22(1):1-2. [PubMed: 24384906]

96. Hacein-Bey-Abina S, Garrigue A, Wang GP, Soulier J, Lim A, Morillon E, Clappier E, Caccavelli L, Delabesse E, Beldjord K, Asnafi V, MacIntyre E, Dal Cortivo L, Radford I, Brousse N, Sigaux F, Moshous D, Hauer J, Borkhardt A, Belohradsky BH, Wintergerst U, Velez MC, Leiva L, Sorensen R, Wulffraat N, Blanche S, Bushman FD, Fischer A, Cavazzana-Calvo M. Insertional oncogenesis in 4 patients after retrovirus-mediated gene therapy of SCID-X1. J Clin Invest. 2008; 118(9):3132-42. [PubMed: 18688285]

97. Xu L, Gao C, Sands MS, Cai SR, Nichols TC, Bellinger DA, Raymer RA, McCorquodale S, Ponder KP. Neonatal or hepatocyte growth factor-potentiated adult gene therapy with a retroviral 
vector results in therapeutic levels of canine factor IX for hemophilia B. Blood. 2003; 101(10): 3924-32. [PubMed: 12531787]

98. Matrai J, Chuah MK, VandenDriessche T. Recent advances in lentiviral vector development and applications. Mol Ther. 2010; 18(3):477-90. [PubMed: 20087315]

99. Naldini L, Blomer U, Gallay P, Ory D, Mulligan R, Gage FH, Verma IM, Trono D. In vivo gene delivery and stable transduction of nondividing cells by a lentiviral vector. Science. 1996; 272(5259):263-7. [PubMed: 8602510]

100. Kobinger GP, Weiner DJ, Yu QC, Wilson JM. Filovirus-pseudotyped lentiviral vector can efficiently and stably transduce airway epithelia in vivo. Nat Biotechnol. 2001; 19(3):225-30. [PubMed: 11231554]

101. Watson DJ, Kobinger GP, Passini MA, Wilson JM, Wolfe JH. Targeted transduction patterns in the mouse brain by lentivirus vectors pseudotyped with VSV, Ebola, Mokola, LCMV, or MuLV envelope proteins. Mol Ther. 2002; 5(5 Pt 1):528-37. [PubMed: 11991743]

102. Wong LF, Azzouz M, Walmsley LE, Askham Z, Wilkes FJ, Mitrophanous KA, Kingsman SM, Mazarakis ND. Transduction patterns of pseudotyped lentiviral vectors in the nervous system. Mol Ther. 2004; 9(1):101-11. [PubMed: 14741783]

103. Sinn PL, Sauter SL, McCray PB Jr. Gene therapy progress and prospects: development of improved lentiviral and retroviral vectors--design, biosafety, and production. Gene Ther. 2005; 12(14):1089-98. [PubMed: 16003340]

104. Baum C. Insertional mutagenesis in gene therapy and stem cell biology. Curr Opin Hematol. 2007; 14(4):337-42. [PubMed: 17534158]

105. Miyoshi H, Blomer U, Takahashi M, Gage FH, Verma IM. Development of a self-inactivating lentivirus vector. J Virol. 1998; 72(10):8150-7. [PubMed: 9733856]

106. Cornils K, Lange C, Schambach A, Brugman MH, Nowak R, Lioznov M, Baum C, Fehse B. Stem cell marking with promotor-deprived self-inactivating retroviral vectors does not lead to induced clonal imbalance. Mol Ther. 2009; 17(1):131-43. [PubMed: 19002163]

107. Montini E, Cesana D, Schmidt M, Sanvito F, Ponzoni M, Bartholomae C, Sergi Sergi L, Benedicenti F, Ambrosi A, Di Serio C, Doglioni C, von Kalle C, Naldini L. Hematopoietic stem cell gene transfer in a tumor-prone mouse model uncovers low genotoxicity of lentiviral vector integration. Nat Biotechnol. 2006; 24(6):687-96. [PubMed: 16732270]

108. Montini E, Cesana D, Schmidt M, Sanvito F, Bartholomae CC, Ranzani M, Benedicenti F, Sergi LS, Ambrosi A, Ponzoni M, Doglioni C, Di Serio C, von Kalle C, Naldini L. The genotoxic potential of retroviral vectors is strongly modulated by vector design and integration site selection in a mouse model of HSC gene therapy. J Clin Invest. 2009; 119(4):964-75. [PubMed: 19307726]

109. Biasco L, Baricordi C, Aiuti A. Retroviral integrations in gene therapy trials. Mol Ther. 2012; 20(4):709-16. [PubMed: 22252453]

110. Chen H, Yao H, Huang L, Shen Q, Jia W, Xue J. Expression of human factor IX gene in murine plasma through lentiviral vector-infected haematopoietic stem cells. Clin Exp Pharmacol Physiol. 2006; 33(12):1196-201. [PubMed: 17184501]

111. Bigger BW, Siapati EK, Mistry A, Waddington SN, Nivsarkar MS, Jacobs L, Perrett R, Holder MV, Ridler C, Kemball-Cook G, Ali RR, Forbes SJ, Coutelle C, Wright N, Alison M, Thrasher AJ, Bonnet D, Themis M. Permanent partial phenotypic correction and tolerance in a mouse model of hemophilia B by stem cell gene delivery of human factor IX. Gene Ther. 2006; 13(2): 117-26. [PubMed: 16163377]

112. Chang AH, Stephan MT, Sadelain M. Stem cell-derived erythroid cells mediate long-term systemic protein delivery. Nat Biotechnol. 2006; 24(8):1017-21. [PubMed: 16845377]

113. Chang AH, Stephan MT, Lisowski L, Sadelain M. Erythroid-specific human factor IX delivery from in vivo selected hematopoietic stem cells following nonmyeloablative conditioning in hemophilia B mice. Mol Ther. 2008; 16(10):1745-52. [PubMed: 18682698]

114. Bowman JE, Reese JS, Lingas KT, Gerson SL. Myeloablation is not required to select and maintain expression of the drug-resistance gene, mutant MGMT, in primary and secondary recipients. Mol Ther. 2003; 8(1):42-50. [PubMed: 12842427] 
115. Sadelain M, Chang A, Lisowski L. Supplying clotting factors from hematopoietic stem cellderived erythroid and megakaryocytic lineage cells. Mol Ther. 2009; 17(12):1994-9. [PubMed: 19844194]

116. Zhang G, Shi Q, Fahs SA, Kuether EL, Walsh CE, Montgomery RR. Factor IX ectopically expressed in platelets can be stored in alpha-granules and corrects the phenotype of hemophilia $\mathrm{B}$ mice. Blood. 2010; 116(8):1235-43. [PubMed: 20445020]

117. Chen Y, Schroeder JA, Kuether EL, Zhang G, Shi Q. Platelet Gene Therapy by Lentiviral Gene Delivery to Hematopoietic Stem Cells Restores Hemostasis and Induces Humoral Immune Tolerance in FIX(null) Mice. Mol Ther. 2014; 22(1):169-77. [PubMed: 24042561]

118. Watanabe N, Ohashi K, Tatsumi K, Utoh R, Shim IK, Kanegae K, Kashiwakura Y, Ohmori T, Sakata Y, Inoue M, Hasegawa M, Okano T. Genetically modified adipose tissue-derived stem/ stromal cells, using simian immunodeficiency virus-based lentiviral vectors, in the treatment of hemophilia B. Hum Gene Ther. 2013; 24(3):283-94. [PubMed: 23360488]

119. Coutu DL, Cuerquis J, El Ayoubi R, Forner KA, Roy R, Francois M, Griffith M, Lillicrap D, Yousefi AM, Blostein MD, Galipeau J. Hierarchical scaffold design for mesenchymal stem cellbased gene therapy of hemophilia B. Biomaterials. 2011; 32(1):295-305. [PubMed: 20864158]

120. Sayyar B, Dodd M, Wen J, Ma S, Marquez-Curtis L, Janowska-Wieczorek A, Hortelano G. Encapsulation of factor IX-engineered mesenchymal stem cells in fibrinogen-alginate microcapsules enhances their viability and transgene secretion. J Tissue Eng. 2012; 3(1): 2041731412462018. [PubMed: 23316273]

121. Sayyar B, Dodd M, Marquez-Curtis L, Janowska-Wieczorek A, Hortelano G. Cell-matrix Interactions of Factor IX (FIX)-engineered human mesenchymal stromal cells encapsulated in RGD-alginate vs. fibrinogen-alginate microcapsules. Artif Cells Nanomed Biotechnol. 2014; 42(2):102-9. [PubMed: 23802745]

122. Sayyar B, Dodd M, Marquez-Curtis L, Janowska-Wieczorek A, Hortelano G. FibronectinAlginate microcapsules improve cell viability and protein secretion of encapsulated Factor IXengineered human mesenchymal stromal cells. Artif Cells Nanomed Biotechnol. 2014

123. Waddington SN, Nivsarkar MS, Mistry AR, Buckley SM, Kemball-Cook G, Mosley KL, Mitrophanous K, Radcliffe P, Holder MV, Brittan M, Georgiadis A, Al-Allaf F, Bigger BW, Gregory LG, Cook HT, Ali RR, Thrasher A, Tuddenham EG, Themis M, Coutelle C. Permanent phenotypic correction of hemophilia B in immunocompetent mice by prenatal gene therapy. Blood. 2004; 104(9):2714-21. [PubMed: 15231566]

124. Chen XG, Zhu HZ, Gong JL, Li F, Xue JL. Efficient delivery of human clotting factor IX after injection of lentiviral vectors in utero. Acta Pharmacol Sin. 2004; 25(6):789-93. [PubMed: 15169633]

125. Chuah MK, Nair N, VandenDriessche T. Recent progress in gene therapy for hemophilia. Hum Gene Ther. 2012; 23(6):557-65. [PubMed: 22671033]

126. Park F, Ohashi K, Kay MA. Therapeutic levels of human factor VIII and IX using HIV-1-based lentiviral vectors in mouse liver. Blood. 2000; 96(3):1173-6. [PubMed: 10910939]

127. Park F, Kay MA. Modified HIV-1 based lentiviral vectors have an effect on viral transduction efficiency and gene expression in vitro and in vivo. Mol Ther. 2001; 4(3):164-73. [PubMed: 11545606]

128. Tsui LV, Kelly M, Zayek N, Rojas V, Ho K, Ge Y, Moskalenko M, Mondesire J, Davis J, Roey MV, Dull T, McArthur JG. Production of human clotting Factor IX without toxicity in mice after vascular delivery of a lentiviral vector. Nat Biotechnol. 2002; 20(1):53-7. [PubMed: 11753362]

129. Follenzi A, Sabatino G, Lombardo A, Boccaccio C, Naldini L. Efficient gene delivery and targeted expression to hepatocytes in vivo by improved lentiviral vectors. Hum Gene Ther. 2002; 13(2):243-60. [PubMed: 11812281]

130. Vigna E, Amendola M, Benedicenti F, Simmons AD, Follenzi A, Naldini L. Efficient Tetdependent expression of human factor IX in vivo by a new self-regulating lentiviral vector. Mol Ther. 2005; 11(5):763-75. [PubMed: 15851015]

131. VandenDriessche T, Thorrez L, Naldini L, Follenzi A, Moons L, Berneman Z, Collen D, Chuah MK. Lentiviral vectors containing the human immunodeficiency virus type- 1 central polypurine 
tract can efficiently transduce nondividing hepatocytes and antigen-presenting cells in vivo. Blood. 2002; 100(3):813-22. [PubMed: 12130491]

132. Follenzi A, Battaglia M, Lombardo A, Annoni A, Roncarolo MG, Naldini L. Targeting lentiviral vector expression to hepatocytes limits transgene-specific immune response and establishes longterm expression of human antihemophilic factor IX in mice. Blood. 2004; 103(10):3700-9. [PubMed: 14701690]

133. Brown BD, Cantore A, Annoni A, Sergi LS, Lombardo A, Della Valle P, D'Angelo A, Naldini L. A microRNA-regulated lentiviral vector mediates stable correction of hemophilia B mice. Blood. 2007; 110(13):4144-52. [PubMed: 17726165]

134. Annoni A, Brown BD, Cantore A, Sergi LS, Naldini L, Roncarolo MG. In vivo delivery of a microRNA-regulated transgene induces antigen-specific regulatory $\mathrm{T}$ cells and promotes immunologic tolerance. Blood. 2009; 114(25):5152-61. [PubMed: 19794140]

135. Annoni A, Cantore A, Della Valle P, Goudy K, Akbarpour M, Russo F, Bartolaccini S, D'Angelo A, Roncarolo MG, Naldini L. Liver gene therapy by lentiviral vectors reverses anti-factor IX preexisting immunity in haemophilic mice. EMBO Mol Med. 2013; 5(11):1684-97. [PubMed: 24106222]

136. Kawai T, Akira S. Toll-like receptors and their crosstalk with other innate receptors in infection and immunity. Immunity. 2011; 34(5):637-50. [PubMed: 21616434]

137. Beignon AS, McKenna K, Skoberne M, Manches O, DaSilva I, Kavanagh DG, Larsson M, Gorelick RJ, Lifson JD, Bhardwaj N. Endocytosis of HIV-1 activates plasmacytoid dendritic cells via Toll-like receptor-viral RNA interactions. J Clin Invest. 2005; 115(11):3265-75. [PubMed: 16224540]

138. Sun L, Wu J, Du F, Chen X, Chen ZJ. Cyclic GMP-AMP synthase is a cytosolic DNA sensor that activates the type I interferon pathway. Science. 2013; 339(6121):786-91. [PubMed: 23258413]

139. Wu J, Sun L, Chen X, Du F, Shi H, Chen C, Chen ZJ. Cyclic GMP-AMP is an endogenous second messenger in innate immune signaling by cytosolic DNA. Science. 2013; 339(6121):82630. [PubMed: 23258412]

140. Ablasser A, Goldeck M, Cavlar T, Deimling T, Witte G, Rohl I, Hopfner KP, Ludwig J, Hornung V. cGAS produces a 2'-5'-linked cyclic dinucleotide second messenger that activates STING. Nature. 2013; 498(7454):380-4. [PubMed: 23722158]

141. Civril F, Deimling T, de Oliveira Mann CC, Ablasser A, Moldt M, Witte G, Hornung V, Hopfner KP. Structural mechanism of cytosolic DNA sensing by cGAS. Nature. 2013; 498(7454):332-7. [PubMed: 23722159]

142. Li XD, Wu J, Gao D, Wang H, Sun L, Chen ZJ. Pivotal roles of cGAS-cGAMP signaling in antiviral defense and immune adjuvant effects. Science. 2013; 341(6152):1390-4. [PubMed: 23989956]

143. Gao D, Wu J, Wu YT, Du F, Aroh C, Yan N, Sun L, Chen ZJ. Cyclic GMP-AMP synthase is an innate immune sensor of HIV and other retroviruses. Science. 2013; 341(6148):903-6. [PubMed: 23929945]

144. Schambach A, Zychlinski D, Ehrnstroem B, Baum C. Biosafety features of lentiviral vectors. Hum Gene Ther. 2013; 24(2):132-42. [PubMed: 23311447]

145. Leavitt AD, Robles G, Alesandro N, Varmus HE. Human immunodeficiency virus type 1 integrase mutants retain in vitro integrase activity yet fail to integrate viral DNA efficiently during infection. J Virol. 1996; 70(2):721-8. [PubMed: 8551608]

146. Vargas J Jr. Gusella GL, Najfeld V, Klotman ME, Cara A. Novel integrase-defective lentiviral episomal vectors for gene transfer. Hum Gene Ther. 2004; 15(4):361-72. [PubMed: 15053861]

147. Saenz DT, Loewen N, Peretz M, Whitwam T, Barraza R, Howell KG, Holmes JM, Good M, Poeschla EM. Unintegrated lentivirus DNA persistence and accessibility to expression in nondividing cells: analysis with class I integrase mutants. J Virol. 2004; 78(6):2906-20. [PubMed: 14990709]

148. Staunstrup NH, Mikkelsen JG. Integrase-defective lentiviral vectors--a stage for nonviral integration machineries. Curr Gene Ther. 2011; 11(5):350-62. [PubMed: 21745178] 
149. Nightingale SJ, Hollis RP, Pepper KA, Petersen D, Yu XJ, Yang C, Bahner I, Kohn DB. Transient gene expression by nonintegrating lentiviral vectors. Mol Ther. 2006; 13(6):1121-32. [PubMed: 16556511]

150. Yanez-Munoz RJ, Balaggan KS, MacNeil A, Howe SJ, Schmidt M, Smith AJ, Buch P, MacLaren RE, Anderson PN, Barker SE, Duran Y, Bartholomae C, von Kalle C, Heckenlively JR, Kinnon C, Ali RR, Thrasher AJ. Effective gene therapy with nonintegrating lentiviral vectors. Nat Med. 2006; 12(3):348-53. [PubMed: 16491086]

151. Philippe S, Sarkis C, Barkats M, Mammeri H, Ladroue C, Petit C, Mallet J, Serguera C. Lentiviral vectors with a defective integrase allow efficient and sustained transgene expression in vitro and in vivo. Proc Natl Acad Sci U S A. 2006; 103(47):17684-9. [PubMed: 17095605]

152. Matrai J, Cantore A, Bartholomae CC, Annoni A, Wang W, Acosta-Sanchez A, Samara-Kuko E, De Waele L, Ma L, Genovese P, Damo M, Arens A, Goudy K, Nichols TC, von Kalle C, MK LC, Roncarolo MG, Schmidt M, Vandendriessche T, Naldini L. Hepatocyte-targeted expression by integrase-defective lentiviral vectors induces antigen-specific tolerance in mice with low genotoxic risk. Hepatology. 2011; 53(5):1696-707. [PubMed: 21520180]

153. Douglas KL. Toward development of artificial viruses for gene therapy: a comparative evaluation of viral and non-viral transfection. Biotechnol Prog. 2008; 24(4):871-83. [PubMed: 18335953]

154. Jafari M, Soltani M, Naahidi S, Karunaratne DN, Chen P. Nonviral approach for targeted nucleic acid delivery. Curr Med Chem. 2012; 19(2):197-208. [PubMed: 22320298]

155. Liu F, Song Y, Liu D. Hydrodynamics-based transfection in animals by systemic administration of plasmid DNA. Gene Ther. 1999; 6(7):1258-66. [PubMed: 10455434]

156. Zhang G, Song YK, Liu D. Long-term expression of human alpha1-antitrypsin gene in mouse liver achieved by intravenous administration of plasmid DNA using a hydrodynamics-based procedure. Gene Ther. 2000; 7(15):1344-9. [PubMed: 10918507]

157. Miao CH, Thompson AR, Loeb K, Ye X. Long-term and therapeutic-level hepatic gene expression of human factor IX after naked plasmid transfer in vivo. Mol Ther. 2001; 3(6):94757. [PubMed: 11407909]

158. Sawyer GJ, Rela M, Davenport M, Whitehorne M, Zhang X, Fabre JW. Hydrodynamic gene delivery to the liver: theoretical and practical issues for clinical application. Curr Gene Ther. 2009; 9(2):128-35. [PubMed: 19355870]

159. Eastman SJ, Baskin KM, Hodges BL, Chu Q, Gates A, Dreusicke R, Anderson S, Scheule RK. Development of catheter-based procedures for transducing the isolated rabbit liver with plasmid DNA. Hum Gene Ther. 2002; 13(17):2065-77. [PubMed: 12490001]

160. Yoshino H, Hashizume K, Kobayashi E. Naked plasmid DNA transfer to the porcine liver using rapid injection with large volume. Gene Ther. 2006; 13(24):1696-702. [PubMed: 16871229]

161. Kamimura K, Suda T, Xu W, Zhang G, Liu D. Image-guided, lobe-specific hydrodynamic gene delivery to swine liver. Mol Ther. 2009; 17(3):491-9. [PubMed: 19156134]

162. Fabre JW, Grehan A, Whitehorne M, Sawyer GJ, Dong X, Salehi S, Eckley L, Zhang X, Seddon M, Shah AM, Davenport M, Rela M. Hydrodynamic gene delivery to the pig liver via an isolated segment of the inferior vena cava. Gene Ther. 2008; 15(6):452-62. [PubMed: 18004400]

163. Hackett PB Jr. Aronovich EL, Hunter D, Urness M, Bell JB, Kass SJ, Cooper LJ, McIvor S. Efficacy and safety of Sleeping Beauty transposon-mediated gene transfer in preclinical animal studies. Curr Gene Ther. 2011; 11(5):341-9. [PubMed: 21888621]

164. VandenDriessche T, Ivics Z, Izsvak Z, Chuah MK. Emerging potential of transposons for gene therapy and generation of induced pluripotent stem cells. Blood. 2009; 114(8):1461-8. [PubMed: 19471016]

165. Fraser MJ, Ciszczon T, Elick T, Bauser C. Precise excision of TTAA-specific lepidopteran transposons piggyBac (IFP2) and tagalong (TFP3) from the baculovirus genome in cell lines from two species of Lepidoptera. Insect Mol Biol. 1996; 5(2):141-51. [PubMed: 8673264]

166. Ding S, Wu X, Li G, Han M, Zhuang Y, Xu T. Efficient transposition of the piggyBac (PB) transposon in mammalian cells and mice. Cell. 2005; 122(3):473-83. [PubMed: 16096065]

167. Ivics Z, Hackett PB, Plasterk RH, Izsvak Z. Molecular reconstruction of Sleeping Beauty, a Tc1like transposon from fish, and its transposition in human cells. Cell. 1997; 91(4):501-10. [PubMed: 9390559] 
168. Izsvak Z, Ivics Z, Plasterk RH. Sleeping Beauty, a wide host-range transposon vector for genetic transformation in vertebrates. J Mol Biol. 2000; 302(1):93-102. [PubMed: 10964563]

169. Mates L, Chuah MK, Belay E, Jerchow B, Manoj N, Acosta-Sanchez A, Grzela DP, Schmitt A, Becker K, Matrai J, Ma L, Samara-Kuko E, Gysemans C, Pryputniewicz D, Miskey C, Fletcher B, VandenDriessche T, Ivics Z, Izsvak Z. Molecular evolution of a novel hyperactive Sleeping Beauty transposase enables robust stable gene transfer in vertebrates. Nat Genet. 2009; 41(6): 753-61. [PubMed: 19412179]

170. Aronovich EL, McIvor RS, Hackett PB. The Sleeping Beauty transposon system: a non-viral vector for gene therapy. Hum Mol Genet. 2011; 20(R1):R14-20. [PubMed: 21459777]

171. Wu SCY, Meir YJJ, Coates CJ, Handler AM, Pelczar P, Moisyadi S, Kaminski JM. piggyBac is a flexible and highly active transposon as compared to Sleeping Beauty, Tol2 and Mos1 in mammalian cells. Proc Natl Acad Sci U S A. 2006; 103(41):15008-15013. [PubMed: 17005721]

172. Xue X, Huang X, Nodland SE, Mates L, Ma L, Izsvak Z, Ivics Z, LeBien TW, McIvor RS, Wagner JE, Zhou X. Stable gene transfer and expression in cord blood-derived CD34+ hematopoietic stem and progenitor cells by a hyperactive Sleeping Beauty transposon system. Blood. 2009; 114(7):1319-30. [PubMed: 19414858]

173. Vigdal TJ, Kaufman CD, Izsvak Z, Voytas DF, Ivics Z. Common physical properties of DNA affecting target site selection of sleeping beauty and other Tc1/mariner transposable elements. J Mol Biol. 2002; 323(3):441-52. [PubMed: 12381300]

174. Yant SR, Wu X, Huang Y, Garrison B, Burgess SM, Kay MA. High-resolution genome-wide mapping of transposon integration in mammals. Mol Cell Biol. 2005; 25(6):2085-94. [PubMed: 15743807]

175. Wilson MH, Coates CJ, George AL Jr. PiggyBac transposon-mediated gene transfer in human cells. Mol Ther. 2007; 15(1):139-45. [PubMed: 17164785]

176. Staunstrup NH, Moldt B, Mates L, Villesen P, Jakobsen M, Ivics Z, Izsvak Z, Mikkelsen JG. Hybrid lentivirus-transposon vectors with a random integration profile in human cells. Mol Ther. 2009; 17(7):1205-14. [PubMed: 19240688]

177. Walisko O, Schorn A, Rolfs F, Devaraj A, Miskey C, Izsvak Z, Ivics Z. Transcriptional activities of the Sleeping Beauty transposon and shielding its genetic cargo with insulators. Mol Ther. 2008; 16(2):359-69. [PubMed: 18071335]

178. Yant SR, Meuse L, Chiu W, Ivics Z, Izsvak Z, Kay MA. Somatic integration and long-term transgene expression in normal and haemophilic mice using a DNA transposon system. Nat Genet. 2000; 25(1):35-41. [PubMed: 10802653]

179. Keravala A, Chavez CL, Hu G, Woodard LE, Monahan PE, Calos MP. Long-term phenotypic correction in factor IX knockout mice by using PhiC31 integrase-mediated gene therapy. Gene Ther. 2011; 18(8):842-8. [PubMed: 21412285]

180. Thorpe HM, Smith MC. In vitro site-specific integration of bacteriophage DNA catalyzed by a recombinase of the resolvase/invertase family. Proc Natl Acad Sci U S A. 1998; 95(10):5505-10. [PubMed: 9576912]

181. Chavez CL, Calos MP. Therapeutic applications of the PhiC31 integrase system. Curr Gene Ther. 2011; 11(5):375-81. [PubMed: 21888619]

182. Yant SR, Ehrhardt A, Mikkelsen JG, Meuse L, Pham T, Kay MA. Transposition from a gutless adeno-transposon vector stabilizes transgene expression in vivo. Nat Biotechnol. 2002; 20(10): 999-1005. [PubMed: 12244327]

183. Hausl MA, Zhang W, Muther N, Rauschhuber C, Franck HG, Merricks EP, Nichols TC, Kay MA, Ehrhardt A. Hyperactive sleeping beauty transposase enables persistent phenotypic correction in mice and a canine model for hemophilia B. Mol Ther. 2010; 18(11):1896-906. [PubMed: 20717103]

184. Hausl M, Zhang W, Voigtlander R, Muther N, Rauschhuber C, Ehrhardt A. Development of adenovirus hybrid vectors for Sleeping Beauty transposition in large mammals. Curr Gene Ther. 2011; 11(5):363-74. [PubMed: 21888620]

185. Ivics Z, Katzer A, Stuwe EE, Fiedler D, Knespel S, Izsvak Z. Targeted Sleeping Beauty transposition in human cells. Mol Ther. 2007; 15(6):1137-44. [PubMed: 17426709] 
186. Gaj T, Gersbach CA, Barbas CF 3rd. ZFN, TALEN, and CRISPR/Cas-based methods for genome engineering. Trends Biotechnol. 2013; 31(7):397-405. [PubMed: 23664777]

187. Liu Q, Segal DJ, Ghiara JB, Barbas CF 3rd. Design of polydactyl zinc-finger proteins for unique addressing within complex genomes. Proc Natl Acad Sci U S A. 1997; 94(11):5525-30. [PubMed: 9159105]

188. Beerli RR, Segal DJ, Dreier B, Barbas CF 3rd. Toward controlling gene expression at will: specific regulation of the erbB-2/HER-2 promoter by using polydactyl zinc finger proteins constructed from modular building blocks. Proc Natl Acad Sci U S A. 1998; 95(25):14628-33. [PubMed: 9843940]

189. Beerli RR, Dreier B, Barbas CF 3rd. Positive and negative regulation of endogenous genes by designed transcription factors. Proc Natl Acad Sci U S A. 2000; 97(4):1495-500. [PubMed: 10660690]

190. Boch J, Scholze H, Schornack S, Landgraf A, Hahn S, Kay S, Lahaye T, Nickstadt A, Bonas U. Breaking the code of DNA binding specificity of TAL-type III effectors. Science. 2009; 326(5959):1509-12. [PubMed: 19933107]

191. Moscou MJ, Bogdanove AJ. A simple cipher governs DNA recognition by TAL effectors. Science. 2009; 326(5959):1501. [PubMed: 19933106]

192. Wiedenheft B, Sternberg SH, Doudna JA. RNA-guided genetic silencing systems in bacteria and archaea. Nature. 2012; 482(7385):331-8. [PubMed: 22337052]

193. Jinek M, Chylinski K, Fonfara I, Hauer M, Doudna JA, Charpentier E. A programmable dualRNA-guided DNA endonuclease in adaptive bacterial immunity. Science. 2012; 337(6096):81621. [PubMed: 22745249]

194. Jinek M, East A, Cheng A, Lin S, Ma E, Doudna J. RNA-programmed genome editing in human cells. Elife. 2013; 2:e00471. [PubMed: 23386978]

195. Cho SW, Kim S, Kim JM, Kim JS. Targeted genome engineering in human cells with the Cas9 RNA-guided endonuclease. Nat Biotechnol. 2013; 31(3):230-2. [PubMed: 23360966]

196. Cong L, Ran FA, Cox D, Lin S, Barretto R, Habib N, Hsu PD, Wu X, Jiang W, Marraffini LA, Zhang F. Multiplex genome engineering using CRISPR/Cas systems. Science. 2013; 339(6121): 819-23. [PubMed: 23287718]

197. Mali P, Yang L, Esvelt KM, Aach J, Guell M, DiCarlo JE, Norville JE, Church GM. RNA-guided human genome engineering via Cas9. Science. 2013; 339(6121):823-6. [PubMed: 23287722]

198. Urnov FD, Miller JC, Lee YL, Beausejour CM, Rock JM, Augustus S, Jamieson AC, Porteus $\mathrm{MH}$, Gregory PD, Holmes MC. Highly efficient endogenous human gene correction using designed zinc-finger nucleases. Nature. 2005; 435(7042):646-51. [PubMed: 15806097]

199. Yusa K, Rashid ST, Strick-Marchand H, Varela I, Liu PQ, Paschon DE, Miranda E, Ordonez A, Hannan NR, Rouhani FJ, Darche S, Alexander G, Marciniak SJ, Fusaki N, Hasegawa M, Holmes MC, Di Santo JP, Lomas DA, Bradley A, Vallier L. Targeted gene correction of alpha1antitrypsin deficiency in induced pluripotent stem cells. Nature. 2011; 478(7369):391-4. [PubMed: 21993621]

200. Zou J, Mali P, Huang X, Dowey SN, Cheng L. Site-specific gene correction of a point mutation in human iPS cells derived from an adult patient with sickle cell disease. Blood. 2011; 118(17): 4599-608. [PubMed: 21881051]

201. Li H, Haurigot V, Doyon Y, Li T, Wong SY, Bhagwat AS, Malani N, Anguela XM, Sharma R, Ivanciu L, Murphy SL, Finn JD, Khazi FR, Zhou S, Paschon DE, Rebar EJ, Bushman FD, Gregory PD, Holmes MC, High KA. In vivo genome editing restores haemostasis in a mouse model of haemophilia. Nature. 2011; 475(7355):217-21. [PubMed: 21706032]

202. Branzei D, Foiani M. Regulation of DNA repair throughout the cell cycle. Nat Rev Mol Cell Biol. 2008; 9(4):297-308. [PubMed: 18285803]

203. Moynahan ME, Jasin M. Mitotic homologous recombination maintains genomic stability and suppresses tumorigenesis. Nat Rev Mol Cell Biol. 2010; 11(3):196-207. [PubMed: 20177395]

204. Anguela XM, Sharma R, Doyon Y, Miller JC, Li H, Haurigot V, Rohde ME, Wong SY, Davidson RJ, Zhou S, Gregory PD, Holmes MC, High KA. Robust ZFN-mediated genome editing in adult hemophilic mice. Blood. 2013; 122(19):3283-7. [PubMed: 24085764] 
205. Rothman S, Tseng H, Goldfine I. Oral gene therapy: a novel method for the manufacture and delivery of protein drugs. Diabetes Technol Ther. 2005; 7(3):549-57. [PubMed: 15929688]

206. Quade-Lyssy P, Milanov P, Abriss D, Ungerer C, Konigs C, Seifried E, Schuttrumpf J. Oral gene therapy for hemophilia B using chitosan formulated FIX muteins. J Thromb Haemost. 2014

207. Verma D, Moghimi B, LoDuca PA, Singh HD, Hoffman BE, Herzog RW, Daniell H. Oral delivery of bioencapsulated coagulation factor IX prevents inhibitor formation and fatal anaphylaxis in hemophilia B mice. Proc Natl Acad Sci U S A. 2010; 107(15):7101-6. [PubMed: 20351275]

208. Wang X, Sherman A, Liao G, Leong KW, Daniell H, Terhorst C, Herzog RW. Mechanism of oral tolerance induction to therapeutic proteins. Adv Drug Deliv Rev. 2013; 65(6):759-73. [PubMed: 23123293]

209. Hershberg R, Petrov DA. Selection on codon bias. Annu Rev Genet. 2008; 42:287-99. [PubMed: 18983258]

210. Ill CR, Chiou HC. Gene therapy progress and prospects: recent progress in transgene and RNAi expression cassettes. Gene Ther. 2005; 12(10):795-802. [PubMed: 15815698]

211. Lin CN, Kao CY, Miao CH, Hamaguchi N, Wu HL, Shi GY, Liu YL, High KA, Lin SW. Generation of a novel factor IX with augmented clotting activities in vitro and in vivo. J Thromb Haemost. 2010; 8(8):1773-83. [PubMed: 20492477]

212. Kao CY, Lin CN, Yu IS, Tao MH, Wu HL, Shi GY, Yang YL, Kao JT, Lin SW. FIX-Triple, a gain-of-function factor IX variant, improves haemostasis in mouse models without increased risk of thrombosis. Thromb Haemost. 2010; 104(2):355-65. [PubMed: 20539913]

213. Simioni P, Tormene D, Tognin G, Gavasso S, Bulato C, Iacobelli NP, Finn JD, Spiezia L, Radu C, Arruda VR. X-linked thrombophilia with a mutant factor IX (factor IX Padua). N Engl J Med. 2009; 361(17):1671-5. [PubMed: 19846852]

214. Cantore A, Nair N, Della Valle P, Di Matteo M, Matrai J, Sanvito F, Brombin C, Di Serio C, D'Angelo A, Chuah M, Naldini L, Vandendriessche T. Hyperfunctional coagulation factor IX improves the efficacy of gene therapy in hemophilic mice. Blood. 2012; 120(23):4517-20. [PubMed: 23043073]

215. Suwanmanee T, Hu G, Gui T, Bartholomae CC, Kutschera I, von Kalle C, Schmidt M, Monahan PE, Kafri T. Integration-deficient Lentiviral Vectors Expressing Codon-optimized R338L Human FIX Restore Normal Hemostasis in Hemophilia B Mice. Mol Ther. 2013

216. Kao CY, Yang SJ, Tao MH, Jeng YM, Yu IS, Lin SW. Incorporation of the factor IX Padua mutation into FIX-Triple improves clotting activity in vitro and in vivo. Thromb Haemost. 2013; 110(2):244-56. [PubMed: 23676890]

217. Fay PJ. Factor VIII structure and function. Int J Hematol. 2006; 83(2):103-8. [PubMed: 16513527]

218. Lynch CM, Israel DI, Kaufman RJ, Miller AD. Sequences in the coding region of clotting factor VIII act as dominant inhibitors of RNA accumulation and protein production. Hum Gene Ther. 1993; 4(3):259-72. [PubMed: 8338874]

219. Kaufman RJ, Wasley LC, Davies MV, Wise RJ, Israel DI, Dorner AJ. Effect of von Willebrand factor coexpression on the synthesis and secretion of factor VIII in Chinese hamster ovary cells. Mol Cell Biol. 1989; 9(3):1233-42. [PubMed: 2498645]

220. Hoeben RC, Fallaux FJ, Cramer SJ, van den Wollenberg DJ, van Ormondt H, Briet E, van der Eb AJ. Expression of the blood-clotting factor-VIII cDNA is repressed by a transcriptional silencer located in its coding region. Blood. 1995; 85(9):2447-54. [PubMed: 7727775]

221. Pipe SW, Kaufman RJ. Factor VIII C2 domain missense mutations exhibit defective trafficking of biologically functional proteins. J Biol Chem. 1996; 271(41):25671-6. [PubMed: 8810344]

222. Dorner AJ, Bole DG, Kaufman RJ. The relationship of N-linked glycosylation and heavy chainbinding protein association with the secretion of glycoproteins. J Cell Biol. 1987; 105(6 Pt 1): 2665-74. [PubMed: 3121636]

223. Dorner AJ, Wasley LC, Kaufman RJ. Overexpression of GRP78 mitigates stress induction of glucose regulated proteins and blocks secretion of selective proteins in Chinese hamster ovary cells. EMBO J. 1992; 11(4):1563-71. [PubMed: 1373378] 
224. Tagliavacca L, Wang Q, Kaufman RJ. ATP-dependent dissociation of non-disulfide-linked aggregates of coagulation factor VIII is a rate-limiting step for secretion. Biochemistry. 2000; 39(8):1973-81. [PubMed: 10684647]

225. Becker S, Simpson JC, Pepperkok R, Heinz S, Herder C, Grez M, Seifried E, Tonn T. Confocal microscopy analysis of native, full length and B-domain deleted coagulation factor VIII trafficking in mammalian cells. Thromb Haemost. 2004; 92(1):23-35. [PubMed: 15213841]

226. Kaufman RJ, Wasley LC, Dorner AJ. Synthesis, processing, and secretion of recombinant human factor VIII expressed in mammalian cells. J Biol Chem. 1988; 263(13):6352-62. [PubMed: 3129422]

227. Montgomery RR, Shi Q. Platelet and endothelial expression of clotting factors for the treatment of hemophilia. Thromb Res. 2012; 129(Suppl 2):S46-8. [PubMed: 22421106]

228. Park SW, Choi SY. Long-term expression of von Willebrand Factor by a VSV-G pseudotyped lentivirus enhances the functional activity of secreted B-Domain-deleted Coagulation Factor VIII. Mol Cells. 2007; 24(1):125-31. [PubMed: 17846507]

229. Nichols WL, Hultin MB, James AH, Manco-Johnson MJ, Montgomery RR, Ortel TL, Rick ME, Sadler JE, Weinstein M, Yawn BP. von Willebrand disease (VWD): evidence-based diagnosis and management guidelines, the National Heart, Lung, and Blood Institute (NHLBI) Expert Panel report (USA). Haemophilia. 2008; 14(2):171-232. [PubMed: 18315614]

230. Weibel ER, Palade GE. New Cytoplasmic Components in Arterial Endothelia. J Cell Biol. 1964; 23:101-12. [PubMed: 14228505]

231. Wagner DD, Olmsted JB, Marder VJ. Immunolocalization of von Willebrand protein in WeibelPalade bodies of human endothelial cells. J Cell Biol. 1982; 95(1):355-60. [PubMed: 6754744]

232. Webster WP, Zukoski CF, Hutchin P, Reddick RL, Mandel SR, Penick GD. Plasma factor VIII synthesis and control as revealed by canine organ transplantation. Am J Physiol. 1971; 220(5): 1147-54. [PubMed: 4930132]

233. Lewis JH, Bontempo FA, Spero JA, Ragni MV, Starzl TE. Liver transplantation in a hemophiliac. N Engl J Med. 1985; 312(18):1189-90. [PubMed: 3920523]

234. Bontempo FA, Lewis JH, Gorenc TJ, Spero JA, Ragni MV, Scott JP, Starzl TE. Liver transplantation in hemophilia A. Blood. 1987; 69(6):1721-4. [PubMed: 3107632]

235. Zelechowska MG, van Mourik JA, Brodniewicz-Proba T. Ultrastructural localization of factor VIII procoagulant antigen in human liver hepatocytes. Nature. 1985; 317(6039):729-30. [PubMed: 3932886]

236. Wion KL, Kelly D, Summerfield JA, Tuddenham EG, Lawn RM. Distribution of factor VIII mRNA and antigen in human liver and other tissues. Nature. 1985; 317(6039):726-9. [PubMed: 3932885]

237. Ingerslev J, Christiansen BS, Heickendorff L, Munck Petersen C. Synthesis of factor VIII in human hepatocytes in culture. Thromb Haemost. 1988; 60(3):387-91. [PubMed: 3149045]

238. Biron-Andreani C, Bezat-Bouchahda C, Raulet E, Pichard-Garcia L, Fabre JM, Saric J, Baulieux J, Schved JF, Maurel P. Secretion of functional plasma haemostasis proteins in long-term primary cultures of human hepatocytes. Br J Haematol. 2004; 125(5):638-46. [PubMed: 15147380]

239. Ohashi K, Waugh JM, Dake MD, Yokoyama T, Kuge H, Nakajima Y, Yamanouchi M, Naka H, Yoshioka A, Kay MA. Liver tissue engineering at extrahepatic sites in mice as a potential new therapy for genetic liver diseases. Hepatology. 2005; 41(1):132-40. [PubMed: 15619229]

240. Hellman L, Smedsrod B, Sandberg H, Pettersson U. Secretion of coagulant factor VIII activity and antigen by in vitro cultivated rat liver sinusoidal endothelial cells. Br J Haematol. 1989; 73(3):348-55. [PubMed: 2513867]

241. Do H, Healey JF, Waller EK, Lollar P. Expression of factor VIII by murine liver sinusoidal endothelial cells. J Biol Chem. 1999; 274(28):19587-92. [PubMed: 10391893]

242. Kumaran V, Benten D, Follenzi A, Joseph B, Sarkar R, Gupta S. Transplantation of endothelial cells corrects the phenotype in hemophilia A mice. J Thromb Haemost. 2005; 3(9):2022-31. [PubMed: 16102109] 
243. Follenzi A, Benten D, Novikoff P, Faulkner L, Raut S, Gupta S. Transplanted endothelial cells repopulate the liver endothelium and correct the phenotype of hemophilia A mice. J Clin Invest. 2008; 118(3):935-45. [PubMed: 18274668]

244. Fomin ME, Zhou Y, Beyer AI, Publicover J, Baron JL, Muench MO. Production of factor VIII by human liver sinusoidal endothelial cells transplanted in immunodeficient uPA mice. PLoS One. 2013; 8(10):e77255. [PubMed: 24167566]

245. Shahani T, Covens K, Lavend'homme R, Jazouli N, Sokal E, Peerlinck K, Jacquemin M. Human liver sinusoidal endothelial cells but not hepatocytes contain factor VIII. J Thromb Haemost. 2014; 12(1):36-42. [PubMed: 24118899]

246. Hollestelle MJ, Thinnes T, Crain K, Stiko A, Kruijt JK, van Berkel TJ, Loskutoff DJ, van Mourik JA. Tissue distribution of factor VIII gene expression in vivo--a closer look. Thromb Haemost. 2001; 86(3):855-61. [PubMed: 11583319]

247. Madeira CL, Layman ME, de Vera RE, Fontes PA, Ragni MV. Extrahepatic factor VIII production in transplant recipient of hemophilia donor liver. Blood. 2009; 113(21):5364-5. [PubMed: 19470440]

248. Jacquemin M, Neyrinck A, Hermanns MI, Lavend'homme R, Rega F, Saint-Remy JM, Peerlinck K, Van Raemdonck D, Kirkpatrick CJ. FVIII production by human lung microvascular endothelial cells. Blood. 2006; 108(2):515-7. [PubMed: 16569771]

249. Hollestelle MJ, Poyck PP, Hollestelle JM, Marsman HA, Mourik JA, Gulik TM. Extra-hepatic factor VIII expression in porcine fulminant hepatic failure. J Thromb Haemost. 2005; 3(10): 2274-80. [PubMed: 16150043]

250. Veltkamp JJ, Asfaou E, van de Torren K, van der Does JA, van Tilburg NH, Pauwels EK. Extrahepatic factor VIII synthesis. Lung transplants in hemophilic dogs. Transplantation. 1974; 18(1):56-62. [PubMed: 4601043]

251. Fahs SA, Hille MT, Shi Q, Weiler H, Montgomery RR. A conditional knockout mouse model reveals endothelial cells as the predominant and possibly exclusive source of plasma factor VIII. Blood. 2014

252. Everett LA, Cleuren AC, Khoriaty RN, Ginsburg D. Murine coagulation factor VIII is synthesized in endothelial cells. Blood. 2014

253. Miao CH, Harmeling BR, Ziegler SF, Yen BC, Torgerson T, Chen L, Yau RJ, Peng B, Thompson $\mathrm{AR}$, Ochs HD, Rawlings DJ. CD4+FOXP3+ regulatory T cells confer long-term regulation of factor VIII-specific immune responses in plasmid-mediated gene therapy-treated hemophilia mice. Blood. 2009; 114(19):4034-44. [PubMed: 19713458]

254. Ye P, Thompson AR, Sarkar R, Shen Z, Lillicrap DP, Kaufman RJ, Ochs HD, Rawlings DJ, Miao $\mathrm{CH}$. Naked DNA transfer of Factor VIII induced transgene-specific, species-independent immune response in hemophilia A mice. Mol Ther. 2004; 10(1):117-26. [PubMed: 15233948]

255. Peng B, Ye P, Blazar BR, Freeman GJ, Rawlings DJ, Ochs HD, Miao CH. Transient blockade of the inducible costimulator pathway generates long-term tolerance to factor VIII after nonviral gene transfer into hemophilia A mice. Blood. 2008; 112(5):1662-72. [PubMed: 18574023]

256. Chao H, Mao L, Bruce AT, Walsh CE. Sustained expression of human factor VIII in mice using a parvovirus-based vector. Blood. 2000; 95(5):1594-9. [PubMed: 10688813]

257. Sack BK, Merchant S, Markusic DM, Nathwani AC, Davidoff AM, Byrne BJ, Herzog RW. Transient B cell depletion or improved transgene expression by codon optimization promote tolerance to factor VIII in gene therapy. PLoS One. 2012; 7(5):e37671. [PubMed: 22655063]

258. Xu L, Mei M, Ma X, Ponder KP. High expression reduces an antibody response after neonatal gene therapy with B domain-deleted human factor VIII in mice. J Thromb Haemost. 2007; 5(9): 1805-12. [PubMed: 17596134]

259. Matsui H, Shibata M, Brown B, Labelle A, Hegadorn C, Andrews C, Chuah M, VandenDriessche T, Miao CH, Hough C, Lillicrap D. A murine model for induction of long-term immunologic tolerance to factor VIII does not require persistent detectable levels of plasma factor VIII and involves contributions from Foxp3+ T regulatory cells. Blood. 2009; 114(3):677-85. [PubMed: 19458355] 
260. Burton M, Nakai H, Colosi P, Cunningham J, Mitchell R, Couto L. Coexpression of factor VIII heavy and light chain adeno-associated viral vectors produces biologically active protein. Proc Natl Acad Sci U S A. 1999; 96(22):12725-30. [PubMed: 10535990]

261. Chen L, Zhu F, Li J, Lu H, Jiang H, Sarkar R, Arruda VR, Wang J, Zhao J, Pierce GF, Ding Q, Wang X, Wang H, Pipe SW, Liu XQ, Xiao X, Camire RM, Xiao W. The enhancing effects of the light chain on heavy chain secretion in split delivery of factor VIII gene. Mol Ther. 2007; 15(10): 1856-62. [PubMed: 17653101]

262. Mah C, Sarkar R, Zolotukhin I, Schleissing M, Xiao X, Kazazian HH, Byrne BJ. Dual vectors expressing murine factor VIII result in sustained correction of hemophilia A mice. Hum Gene Ther. 2003; 14(2):143-52. [PubMed: 12614565]

263. Sarkar R, Xiao W, Kazazian HH Jr. A single adeno-associated virus (AAV)-murine factor VIII vector partially corrects the hemophilia A phenotype. J Thromb Haemost. 2003; 1(2):220-6. [PubMed: 12871492]

264. Pittman DD, Alderman EM, Tomkinson KN, Wang JH, Giles AR, Kaufman RJ. Biochemical, immunological, and in vivo functional characterization of B-domain-deleted factor VIII. Blood. 1993; 81(11):2925-35. [PubMed: 8499631]

265. Ishiwata A, Mimuro J, Kashiwakura Y, Niimura M, Takano K, Ohmori T, Madoiwa S, Mizukami H, Okada T, Naka H, Yoshioka A, Ozawa K, Sakata Y. Phenotype correction of hemophilia A mice with adeno-associated virus vectors carrying the B domain-deleted canine factor VIII gene. Thromb Res. 2006; 118(5):627-35. [PubMed: 16371232]

266. Scallan CD, Lillicrap D, Jiang H, Qian X, Patarroyo-White SL, Parker AE, Liu T, Vargas J, Nagy D, Powell SK, Wright JF, Turner PV, Tinlin SJ, Webster SE, McClelland A, Couto LB. Sustained phenotypic correction of canine hemophilia A using an adeno-associated viral vector. Blood. 2003; 102(6):2031-7. [PubMed: 12738670]

267. Jiang H, Lillicrap D, Patarroyo-White S, Liu T, Qian X, Scallan CD, Powell S, Keller T, McMurray M, Labelle A, Nagy D, Vargas JA, Zhou S, Couto LB, Pierce GF. Multiyear therapeutic benefit of AAV serotypes 2, 6, and 8 delivering factor VIII to hemophilia A mice and dogs. Blood. 2006; 108(1):107-15. [PubMed: 16522813]

268. Sabatino DE, Lange AM, Altynova ES, Sarkar R, Zhou S, Merricks EP, Franck HG, Nichols TC, Arruda VR, Kazazian HH Jr. Efficacy and safety of long-term prophylaxis in severe hemophilia A dogs following liver gene therapy using AAV vectors. Mol Ther. 2011; 19(3):442-9. [PubMed: 21081906]

269. Finn JD, Ozelo MC, Sabatino DE, Franck HW, Merricks EP, Crudele JM, Zhou S, Kazazian HH, Lillicrap D, Nichols TC, Arruda VR. Eradication of neutralizing antibodies to factor VIII in canine hemophilia A after liver gene therapy. Blood. 2010; 116(26):5842-8. [PubMed: 20876851]

270. High KA. The gene therapy journey for hemophilia: are we there yet? Blood. 2012

271. Lu H, Chen L, Wang J, Huack B, Sarkar R, Zhou S, Xu R, Ding Q, Wang X, Wang H, Xiao W. Complete correction of hemophilia A with adeno-associated viral vectors containing a full-size expression cassette. Hum Gene Ther. 2008; 19(6):648-54. [PubMed: 18500941]

272. Zhou X, Muzyczka N. In vitro packaging of adeno-associated virus DNA. J Virol. 1998; 72(4): 3241-7. [PubMed: 9525651]

273. Allocca M, Doria M, Petrillo M, Colella P, Garcia-Hoyos M, Gibbs D, Kim SR, Maguire A, Rex TS, Di Vicino U, Cutillo L, Sparrow JR, Williams DS, Bennett J, Auricchio A. Serotypedependent packaging of large genes in adeno-associated viral vectors results in effective gene delivery in mice. J Clin Invest. 2008; 118(5):1955-64. [PubMed: 18414684]

274. Wu Z, Yang H, Colosi P. Effect of genome size on AAV vector packaging. Mol Ther. 2010; 18(1):80-6. [PubMed: 19904234]

275. Lai Y, Yue Y, Duan D. Evidence for the failure of adeno-associated virus serotype 5 to package a viral genome > or = 8.2 kb. Mol Ther. 2010; 18(1):75-9. [PubMed: 19904238]

276. Hirsch ML, Agbandje-McKenna M, Samulski RJ. Little vector, big gene transduction: fragmented genome reassembly of adeno-associated virus. Mol Ther. 2010; 18(1):6-8. [PubMed: 20048740] 
277. Dong B, Nakai H, Xiao W. Characterization of genome integrity for oversized recombinant AAV vector. Mol Ther. 2010; 18(1):87-92. [PubMed: 19904236]

278. Duan D, Yue Y, Yan Z, Yang J, Engelhardt JF. Endosomal processing limits gene transfer to polarized airway epithelia by adeno-associated virus. J Clin Invest. 2000; 105(11):1573-87. [PubMed: 10841516]

279. Douar AM, Poulard K, Stockholm D, Danos O. Intracellular trafficking of adeno-associated virus vectors: routing to the late endosomal compartment and proteasome degradation. J Virol. 2001; 75(4):1824-33. [PubMed: 11160681]

280. Monahan PE, Lothrop CD, Sun J, Hirsch ML, Kafri T, Kantor B, Sarkar R, Tillson DM, Elia JR, Samulski RJ. Proteasome inhibitors enhance gene delivery by AAV virus vectors expressing large genomes in hemophilia mouse and dog models: a strategy for broad clinical application. Mol Ther. 2010; 18(11):1907-16. [PubMed: 20700109]

281. Ishiwata A, Mimuro J, Mizukami H, Kashiwakura Y, Takano K, Ohmori T, Madoiwa S, Ozawa K, Sakata Y. Liver-restricted expression of the canine factor VIII gene facilitates prevention of inhibitor formation in factor VIII-deficient mice. J Gene Med. 2009; 11(11):1020-9. [PubMed: 19757487]

282. Hu C, Lipshutz GS. AAV-based neonatal gene therapy for hemophilia A: long-term correction and avoidance of immune responses in mice. Gene Ther. 2012; 19(12):1166-76. [PubMed: 22241178]

283. Ward NJ, Buckley SM, Waddington SN, Vandendriessche T, Chuah MK, Nathwani AC, McIntosh J, Tuddenham EG, Kinnon C, Thrasher AJ, McVey JH. Codon optimization of human factor VIII cDNAs leads to high-level expression. Blood. 2011; 117(3):798-807. [PubMed: 21041718]

284. McIntosh J, Lenting PJ, Rosales C, Lee D, Rabbanian S, Raj D, Patel N, Tuddenham EG, Christophe OD, McVey JH, Waddington S, Nienhuis AW, Gray JT, Fagone P, Mingozzi F, Zhou SZ, High KA, Cancio M, Ng CY, Zhou J, Morton CL, Davidoff AM, Nathwani AC. Therapeutic levels of FVIII following a single peripheral vein administration of rAAV vector encoding a novel human factor VIII variant. Blood. 2013; 121(17):3335-44. [PubMed: 23426947]

285. VandenDriessche T, Vanslembrouck V, Goovaerts I, Zwinnen H, Vanderhaeghen ML, Collen D, Chuah MK. Long-term expression of human coagulation factor VIII and correction of hemophilia A after in vivo retroviral gene transfer in factor VIII-deficient mice. Proc Natl Acad Sci U S A. 1999; 96(18):10379-84. [PubMed: 10468616]

286. Xu L, Nichols TC, Sarkar R, McCorquodale S, Bellinger DA, Ponder KP. Absence of a desmopressin response after therapeutic expression of factor VIII in hemophilia A dogs with liver-directed neonatal gene therapy. Proc Natl Acad Sci U S A. 2005; 102(17):6080-5. [PubMed: 15837921]

287. Powell JS, Ragni MV, White GC 2nd, Lusher JM, Hillman-Wiseman C, Moon TE, Cole V, Ramanathan-Girish S, Roehl H, Sajjadi N, Jolly DJ, Hurst D. Phase 1 trial of FVIII gene transfer for severe hemophilia A using a retroviral construct administered by peripheral intravenous infusion. Blood. 2003; 102(6):2038-45. [PubMed: 12763932]

288. McCormack JE, Edwards W, Sensintaffer J, Lillegren L, Kozloski M, Brumm D, Karavodin L, Jolly DJ, Greengard J. Factors affecting long-term expression of a secreted transgene product after intravenous administration of a retroviral vector. Mol Ther. 2001; 3(4):516-25. [PubMed: 11319912]

289. Roehl HH, Leibbrandt ME, Greengard JS, Kamantigue E, Glass WG, Giedlin M, Boekelheide K, Johnson DE, Jolly DJ, Sajjadi NC. Analysis of testes and semen from rabbits treated by intravenous injection with a retroviral vector encoding the human factor VIII gene: no evidence of germ line transduction. Hum Gene Ther. 2000; 11(18):2529-40. [PubMed: 11119423]

290. Kootstra NA, Matsumura R, Verma IM. Efficient production of human FVIII in hemophilic mice using lentiviral vectors. Mol Ther. 2003; 7(5 Pt 1):623-31. [PubMed: 12718905]

291. Park F. Correction of bleeding diathesis without liver toxicity using arenaviral-pseudotyped HIV-1-based vectors in hemophilia A mice. Hum Gene Ther. 2003; 14(15):1489-94. [PubMed: 14577928]

292. Ogata K, Mimuro J, Kikuchi J, Tabata T, Ueda Y, Naito M, Madoiwa S, Takano K, Hasegawa M, Ozawa K, Sakata Y. Expression of human coagulation factor VIII in adipocytes transduced with 
the simian immunodeficiency virus agmTYO1-based vector for hemophilia A gene therapy. Gene Ther. 2004; 11(3):253-9. [PubMed: 14737084]

293. Stein CS, Kang Y, Sauter SL, Townsend K, Staber P, Derksen TA, Martins I, Qian J, Davidson BL, McCray PB Jr. In vivo treatment of hemophilia A and mucopolysaccharidosis type VII using nonprimate lentiviral vectors. Mol Ther. 2001; 3(6):850-6. [PubMed: 11407898]

294. Kang Y, Xie L, Tran DT, Stein CS, Hickey M, Davidson BL, McCray PB Jr. Persistent expression of factor VIII in vivo following nonprimate lentiviral gene transfer. Blood. 2005; 106(5):1552-8. [PubMed: 15886327]

295. Sinn PL, Goreham-Voss JD, Arias AC, Hickey MA, Maury W, Chikkanna-Gowda CP, McCray PB Jr. Enhanced gene expression conferred by stepwise modification of a nonprimate lentiviral vector. Hum Gene Ther. 2007; 18(12):1244-52. [PubMed: 18052720]

296. Matsui H, Hegadorn C, Ozelo M, Burnett E, Tuttle A, Labelle A, McCray PB Jr. Naldini L, Brown B, Hough C, Lillicrap D. A microRNA-regulated and GP64-pseudotyped lentiviral vector mediates stable expression of FVIII in a murine model of Hemophilia A. Mol Ther. 2011; 19(4): 723-30. [PubMed: 21285959]

297. Abel T, El Filali E, Waern J, Schneider IC, Yuan Q, Munch RC, Hick M, Warnecke G, Madrahimov N, Kontermann RE, Schuttrumpf J, Muller UC, Seppen J, Ott M, Buchholz CJ. Specific gene delivery to liver sinusoidal and artery endothelial cells. Blood. 2013; 122(12): 2030-8. [PubMed: 23884859]

298. Vandendriessche T, Chuah MK. Targeting endothelial cells by gene therapy. Blood. 2013; 122(12):1993-4. [PubMed: 24052537]

299. Hoeben RC, Einerhand MP, Briet E, van Ormondt H, Valerio D, van der Eb AJ. Toward gene therapy in haemophilia A: retrovirus-mediated transfer of a factor VIII gene into murine haematopoietic progenitor cells. Thromb Haemost. 1992; 67(3):341-5. [PubMed: 1641825]

300. Evans GL, Morgan RA. Genetic induction of immune tolerance to human clotting factor VIII in a mouse model for hemophilia A. Proc Natl Acad Sci U S A. 1998; 95(10):5734-9. [PubMed: 9576953]

301. Ramezani A, Hawley RG. Correction of murine hemophilia A following nonmyeloablative transplantation of hematopoietic stem cells engineered to encode an enhanced human factor VIII variant using a safety-augmented retroviral vector. Blood. 2009; 114(3):526-34. [PubMed: 19470695]

302. Moayeri M, Ramezani A, Morgan RA, Hawley TS, Hawley RG. Sustained phenotypic correction of hemophilia a mice following oncoretroviral-mediated expression of a bioengineered human factor VIII gene in long-term hematopoietic repopulating cells. Mol Ther. 2004; 10(5):892-902. [PubMed: 15509507]

303. Ide LM, Iwakoshi NN, Gangadharan B, Jobe S, Moot R, McCarty D, Doering CB, Spencer HT. Functional aspects of factor VIII expression after transplantation of genetically-modified hematopoietic stem cells for hemophilia A. J Gene Med. 2010; 12(4):333-44. [PubMed: 20209485]

304. Ide LM, Gangadharan B, Chiang KY, Doering CB, Spencer HT. Hematopoietic stem-cell gene therapy of hemophilia A incorporating a porcine factor VIII transgene and nonmyeloablative conditioning regimens. Blood. 2007; 110(8):2855-63. [PubMed: 17569821]

305. Van Damme A, Thorrez L, Ma L, Vandenburgh H, Eyckmans J, Dell'Accio F, De Bari C, Luyten F, Lillicrap D, Collen D, VandenDriessche T, Chuah MK. Efficient lentiviral transduction and improved engraftment of human bone marrow mesenchymal cells. Stem Cells. 2006; 24(4):896907. [PubMed: 16339997]

306. Tiede A, Eder M, von Depka M, Battmer K, Luther S, Kiem HP, Ganser A, Scherr M. Recombinant factor VIII expression in hematopoietic cells following lentiviral transduction. Gene Ther. 2003; 10(22):1917-25. [PubMed: 14502221]

307. Kikuchi J, Mimuro J, Ogata K, Tabata T, Ueda Y, Ishiwata A, Kimura K, Takano K, Madoiwa S, Mizukami H, Hanazono Y, Kume A, Hasegawa M, Ozawa K, Sakata Y. Sustained transgene expression by human cord blood derived CD34+ cells transduced with simian immunodeficiency virus agmTYO1-based vectors carrying the human coagulation factor VIII gene in NOD/SCID mice. J Gene Med. 2004; 6(10):1049-60. [PubMed: 15386735] 
308. Herder C, Tonn T, Oostendorp R, Becker S, Keller U, Peschel C, Grez M, Seifried E. Sustained expansion and transgene expression of coagulation factor VIII-transduced cord blood-derived endothelial progenitor cells. Arterioscler Thromb Vasc Biol. 2003; 23(12):2266-72. [PubMed: 14551158]

309. Ramezani A, Zweier-Renn LA, Hawley RG. Factor VIII delivered by haematopoietic stem cellderived B cells corrects the phenotype of haemophilia A mice. Thromb Haemost. 2011; 105(4): 676-87. [PubMed: 21264447]

310. Kanaji S, Fahs SA, Shi Q, Haberichter SL, Montgomery RR. Contribution of platelet vs. endothelial VWF to platelet adhesion and hemostasis. J Thromb Haemost. 2012; 10(8):1646-52. [PubMed: 22642380]

311. Yarovoi HV, Kufrin D, Eslin DE, Thornton MA, Haberichter SL, Shi Q, Zhu H, Camire R, Fakharzadeh SS, Kowalska MA, Wilcox DA, Sachais BS, Montgomery RR, Poncz M. Factor VIII ectopically expressed in platelets: efficacy in hemophilia A treatment. Blood. 2003; 102(12): 4006-13. [PubMed: 12881300]

312. Shi Q, Wilcox DA, Fahs SA, Weiler H, Wells CW, Cooley BC, Desai D, Morateck PA, Gorski J, Montgomery RR. Factor VIII ectopically targeted to platelets is therapeutic in hemophilia A with high-titer inhibitory antibodies. J Clin Invest. 2006; 116(7):1974-82. [PubMed: 16823491]

313. Shi Q, Wilcox DA, Fahs SA, Fang J, Johnson BD, Du LM, Desai D, Montgomery RR. Lentivirus-mediated platelet-derived factor VIII gene therapy in murine haemophilia A. J Thromb Haemost. 2007; 5(2):352-61. [PubMed: 17269937]

314. Ohmori T, Mimuro J, Takano K, Madoiwa S, Kashiwakura Y, Ishiwata A, Niimura M, Mitomo K, Tabata T, Hasegawa M, Ozawa K, Sakata Y. Efficient expression of a transgene in platelets using simian immunodeficiency virus-based vector harboring glycoprotein Ibalpha promoter: in vivo model for platelet-targeting gene therapy. FASEB J. 2006; 20(9):1522-4. [PubMed: 16723382]

315. Du LM, Nurden P, Nurden AT, Nichols TC, Bellinger DA, Jensen ES, Haberichter SL, Merricks E, Raymer RA, Fang J, Koukouritaki SB, Jacobi PM, Hawkins TB, Cornetta K, Shi Q, Wilcox DA. Platelet-targeted gene therapy with human factor VIII establishes haemostasis in dogs with haemophilia A. Nat Commun. 2013; 4:2773. [PubMed: 24253479]

316. Shi Q, Kuether EL, Chen Y, Schroeder JA, Fahs SA, Montgomery RR. Platelet gene therapy corrects the hemophilic phenotype in immunocompromised hemophilia A mice transplanted with genetically manipulated human cord blood stem cells. Blood. 2014; 123(3):395-403. [PubMed: 24269957]

317. Kuether EL, Schroeder JA, Fahs SA, Cooley BC, Chen Y, Montgomery RR, Wilcox DA, Shi Q. Lentivirus-mediated platelet gene therapy of murine hemophilia A with pre-existing anti-factor VIII immunity. J Thromb Haemost. 2012; 10(8):1570-80. [PubMed: 22632092]

318. Coleman MA, Bridge JA, Lane SW, Dixon CM, Hill GR, Wells JW, Thomas R, Steptoe RJ. Tolerance induction with gene-modified stem cells and immune-preserving conditioning in primed mice: restricting antigen to differentiated antigen-presenting cells permits efficacy. Blood. 2013; 121(6):1049-58. [PubMed: 23233664]

319. Gewirtz J, Thornton MA, Rauova L, Poncz M. Platelet-delivered factor VIII provides limited resistance to anti-factor VIII inhibitors. J Thromb Haemost. 2008; 6(7):1160-6. [PubMed: 18433455]

320. Greene TK, Wang C, Hirsch JD, Zhai L, Gewirtz J, Thornton MA, Miao HZ, Pipe SW, Kaufman RJ, Camire RM, Arruda VR, Kowalska MA, Poncz M. In vivo efficacy of platelet-delivered, high specific activity factor VIII variants. Blood. 2010; 116(26):6114-22. [PubMed: 20852129]

321. Doering CB. Retroviral modification of mesenchymal stem cells for gene therapy of hemophilia. Methods Mol Biol. 2008; 433:203-12. [PubMed: 18679625]

322. Van Damme A, Chuah MK, Dell'accio F, De Bari C, Luyten F, Collen D, VandenDriessche T. Bone marrow mesenchymal cells for haemophilia A gene therapy using retroviral vectors with modified long-terminal repeats. Haemophilia. 2003; 9(1):94-103. [PubMed: 12558785]

323. Kashiwakura Y, Ohmori T, Mimuro J, Yasumoto A, Ishiwata A, Sakata A, Madoiwa S, Inoue M, Hasegawa M, Ozawa K, Sakata Y. Intra-articular injection of mesenchymal stem cells expressing coagulation factor ameliorates hemophilic arthropathy in factor VIII-deficient mice. J Thromb Haemost. 2012; 10(9):1802-13. [PubMed: 22784361] 
324. Porada CD, Sanada C, Kuo CJ, Colletti E, Mandeville W, Hasenau J, Zanjani ED, Moot R, Doering C, Spencer HT, Almeida-Porada G. Phenotypic correction of hemophilia A in sheep by postnatal intraperitoneal transplantation of FVIII-expressing MSC. Exp Hematol. 2011; 39(12): 1124-1135. e4. [PubMed: 21906573]

325. Matsui H, Shibata M, Brown B, Labelle A, Hegadorn C, Andrews C, Hebbel RP, Galipeau J, Hough C, Lillicrap D. Ex vivo gene therapy for hemophilia A that enhances safe delivery and sustained in vivo factor VIII expression from lentivirally engineered endothelial progenitors. Stem Cells. 2007; 25(10):2660-9. [PubMed: 17615271]

326. Tatsumi K, Sugimoto M, Lillicrap D, Shima M, Ohashi K, Okano T, Matsui H. A Novel CellSheet Technology That Achieves Durable Factor VIII Delivery in a Mouse Model of Hemophilia A. PLoS One. 2013; 8(12):e83280. [PubMed: 24358271]

327. Ozelo MC, Vidal B, Brown C, Notley C, Hegadorn C, Webster S, Harpell L, Ahlin J, Winterborn A, Handforth J, Arruda VR, Hough C, Lillicrap D. Omental implantation of BOECs in hemophilia dogs results in circulating FVIII antigen and a complex immune response. Blood. 2014; 123(26):4045-53. [PubMed: 24829206]

328. de Lazaro I, Yilmazer A, Kostarelos K. Induced pluripotent stem (iPS) cells: A new source for cell-based therapeutics? J Control Release. 2014; 185C:37-44. [PubMed: 24746625]

329. Kashiwakura Y, Ohmori T, Mimuro J, Madoiwa S, Inoue M, Hasegawa M, Ozawa K, Sakata Y. Production of functional coagulation factor VIII from iPSCs using a lentiviral vector. Haemophilia. 2014; 20(1):e40-4. [PubMed: 24354485]

330. Miao CH, Ye P, Thompson AR, Rawlings DJ, Ochs HD. Immunomodulation of transgene responses following naked DNA transfer of human factor VIII into hemophilia A mice. Blood. 2006; 108(1):19-27. [PubMed: 16507778]

331. Peng B, Ye P, Rawlings DJ, Ochs HD, Miao CH. Anti-CD3 antibodies modulate anti-factor VIII immune responses in hemophilia A mice after factor VIII plasmid-mediated gene therapy. Blood. 2009; 114(20):4373-82. [PubMed: 19770362]

332. Wang J, Mansfield SG, Cote CA, Jiang PD, Weng K, Amar MJ, Brewer BH Jr. Remaley AT, McGarrity GJ, Garcia-Blanco MA, Puttaraju M. Trans-splicing into highly abundant albumin transcripts for production of therapeutic proteins in vivo. Mol Ther. 2009; 17(2):343-51. [PubMed: 19066600]

333. Chao H, Mansfield SG, Bartel RC, Hiriyanna S, Mitchell LG, Garcia-Blanco MA, Walsh CE. Phenotype correction of hemophilia A mice by spliceosome-mediated RNA trans-splicing. Nat Med. 2003; 9(8):1015-9. [PubMed: 12847523]

334. Ohlfest JR, Frandsen JL, Fritz S, Lobitz PD, Perkinson SG, Clark KJ, Nelsestuen G, Key NS, McIvor RS, Hackett PB, Largaespada DA. Phenotypic correction and long-term expression of factor VIII in hemophilic mice by immunotolerization and nonviral gene transfer using the Sleeping Beauty transposon system. Blood. 2005; 105(7):2691-8. [PubMed: 15576475]

335. Liu L, Mah C, Fletcher BS. Sustained FVIII expression and phenotypic correction of hemophilia A in neonatal mice using an endothelial-targeted sleeping beauty transposon. Mol Ther. 2006; 13(5):1006-15. [PubMed: 16464640]

336. Liu L, Liu H, Mah C, Fletcher BS. Indoleamine 2,3-dioxygenase attenuates inhibitor development in gene-therapy-treated hemophilia A mice. Gene Ther. 2009; 16(6):724-33. [PubMed: 19262614]

337. Kren BT, Unger GM, Sjeklocha L, Trossen AA, Korman V, Diethelm-Okita BM, Reding MT, Steer CJ. Nanocapsule-delivered Sleeping Beauty mediates therapeutic Factor VIII expression in liver sinusoidal endothelial cells of hemophilia A mice. J Clin Invest. 2009; 119(7):2086-99. [PubMed: 19509468]

338. Bowman K, Sarkar R, Raut S, Leong KW. Gene transfer to hemophilia A mice via oral delivery of FVIII-chitosan nanoparticles. J Control Release. 2008; 132(3):252-9. [PubMed: 18634839]

339. Dhadwar SS, Kiernan J, Wen J, Hortelano G. Repeated oral administration of chitosan/DNA nanoparticles delivers functional FVIII with the absence of antibodies in hemophilia A mice. J Thromb Haemost. 2010; 8(12):2743-50. [PubMed: 20961391] 
340. Roth DA, Tawa NE Jr. O'Brien JM, Treco DA, Selden RF. Nonviral transfer of the gene encoding coagulation factor VIII in patients with severe hemophilia A. N Engl J Med. 2001; 344(23): 1735-42. [PubMed: 11396439]

341. Lin Y, Weisdorf DJ, Solovey A, Hebbel RP. Origins of circulating endothelial cells and endothelial outgrowth from blood. J Clin Invest. 2000; 105(1):71-7. [PubMed: 10619863]

342. Lin Y, Chang L, Solovey A, Healey JF, Lollar P, Hebbel RP. Use of blood outgrowth endothelial cells for gene therapy for hemophilia A. Blood. 2002; 99(2):457-62. [PubMed: 11781225]

343. Somani A, Nguyen J, Milbauer LC, Solovey A, Sajja S, Hebbel RP. The establishment of murine blood outgrowth endothelial cells and observations relevant to gene therapy. Transl Res. 2007; 150(1):30-9. [PubMed: 17585861]

344. Liu X, Liu M, Xue Z, Pan Q, Wu L, Long Z, Xia K, Liang D, Xia J. Non-viral ex vivo transduction of human hepatocyte cells to express factor VIII using a human ribosomal DNAtargeting vector. J Thromb Haemost. 2007; 5(2):347-51. [PubMed: 17155951]

345. Kasuda S, Kubo A, Sakurai Y, Irion S, Ohashi K, Tatsumi K, Nakajima Y, Saito Y, Hatake K, Pipe SW, Shima M, Yoshioka A. Establishment of embryonic stem cells secreting human factor VIII for cell-based treatment of hemophilia A. J Thromb Haemost. 2008; 6(8):1352-9. [PubMed: 18485084]

346. Xu D, Alipio Z, Fink LM, Adcock DM, Yang J, Ward DC, Ma Y. Phenotypic correction of murine hemophilia A using an iPS cell-based therapy. Proc Natl Acad Sci U S A. 2009; 106(3): 808-13. [PubMed: 19139414]

347. Oshimura M, Katoh M. Transfer of human artificial chromosome vectors into stem cells. Reprod Biomed Online. 2008; 16(1):57-69. [PubMed: 18252049]

348. Kazuki Y, Oshimura M. Human artificial chromosomes for gene delivery and the development of animal models. Mol Ther. 2011; 19(9):1591-601. [PubMed: 21750534]

349. Kazuki Y, Hoshiya H, Takiguchi M, Abe S, Iida Y, Osaki M, Katoh M, Hiratsuka M, Shirayoshi Y, Hiramatsu K, Ueno E, Kajitani N, Yoshino T, Kazuki K, Ishihara C, Takehara S, Tsuji S, Ejima F, Toyoda A, Sakaki Y, Larionov V, Kouprina N, Oshimura M. Refined human artificial chromosome vectors for gene therapy and animal transgenesis. Gene Ther. 2011; 18(4):384-93. [PubMed: 21085194]

350. Katoh M, Ayabe F, Norikane S, Okada T, Masumoto H, Horike S, Shirayoshi Y, Oshimura M. Construction of a novel human artificial chromosome vector for gene delivery. Biochem Biophys Res Commun. 2004; 321(2):280-90. [PubMed: 15358173]

351. Yakura Y, Ishihara C, Kurosaki H, Kazuki Y, Komatsu N, Okada Y, Doi T, Takeya H, Oshimura M. An induced pluripotent stem cell-mediated and integration-free factor VIII expression system. Biochem Biophys Res Commun. 2013; 431(2):336-41. [PubMed: 23291180]

352. Doering CB, Healey JF, Parker ET, Barrow RT, Lollar P. Identification of porcine coagulation factor VIII domains responsible for high level expression via enhanced secretion. J Biol Chem. 2004; 279(8):6546-52. [PubMed: 14660593]

353. Doering CB, Healey JF, Parker ET, Barrow RT, Lollar P. High level expression of recombinant porcine coagulation factor VIII. J Biol Chem. 2002; 277(41):38345-9. [PubMed: 12138172]

354. Brown HC, Gangadharan B, Doering CB. Enhanced biosynthesis of coagulation factor VIII through diminished engagement of the unfolded protein response. J Biol Chem. 2011; 286(27): 24451-7. [PubMed: 21606503]

355. Gangadharan B, Parker ET, Ide LM, Spencer HT, Doering CB. High-level expression of porcine factor VIII from genetically modified bone marrow-derived stem cells. Blood. 2006; 107(10): 3859-64. [PubMed: 16449528]

356. Johnston JM, Denning G, Doering CB, Spencer HT. Generation of an optimized lentiviral vector encoding a high-expression factor VIII transgene for gene therapy of hemophilia A. Gene Ther. 2013; 20(6):607-15. [PubMed: 22996197]

357. Dooriss KL, Denning G, Gangadharan B, Javazon EH, McCarty DA, Spencer HT, Doering CB. Comparison of factor VIII transgenes bioengineered for improved expression in gene therapy of hemophilia A. Hum Gene Ther. 2009; 20(5):465-78. [PubMed: 19222367] 
358. Doering CB, Denning G, Dooriss K, Gangadharan B, Johnston JM, Kerstann KW, McCarty DA, Spencer HT. Directed engineering of a high-expression chimeric transgene as a strategy for gene therapy of hemophilia A. Mol Ther. 2009; 17(7):1145-54. [PubMed: 19259064]

359. Parker ET, Healey JF, Barrow RT, Craddock HN, Lollar P. Reduction of the inhibitory antibody response to human factor VIII in hemophilia A mice by mutagenesis of the A2 domain B-cell epitope. Blood. 2004; 104(3):704-10. [PubMed: 15073030]

360. Kempton CL, Abshire TC, Deveras RA, Hoots WK, Gill JC, Kessler CM, Key NS, Konkle BA, Kuriakose P, Macfarlane DE, Bergman G. Pharmacokinetics and safety of OBI-1, a recombinant B domain-deleted porcine factor VIII, in subjects with haemophilia A. Haemophilia. 2012; 18(5): 798-804. [PubMed: 22512291]

361. Healey JF, Parker ET, Barrow RT, Langley TJ, Church WR, Lollar P. The comparative immunogenicity of human and porcine factor VIII in haemophilia A mice. Thromb Haemost. 2009; 102(1):35-41. [PubMed: 19572065]

362. Doering CB, Gangadharan B, Dukart HZ, Spencer HT. Hematopoietic stem cells encoding porcine factor VIII induce pro-coagulant activity in hemophilia A mice with pre-existing factor VIII immunity. Mol Ther. 2007; 15(6):1093-9. [PubMed: 17387335]

363. Sabatino DE, Freguia CF, Toso R, Santos A, Merricks EP, Kazazian HH Jr. Nichols TC, Camire RM, Arruda VR. Recombinant canine B-domain-deleted FVIII exhibits high specific activity and is safe in the canine hemophilia A model. Blood. 2009; 114(20):4562-5. [PubMed: 19770361]

364. Siner JI, Iacobelli NP, Sabatino DE, Ivanciu L, Zhou S, Poncz M, Camire RM, Arruda VR. Minimal modification in the factor VIII B-domain sequence ameliorates the murine hemophilia A phenotype. Blood. 2013; 121(21):4396-403. [PubMed: 23372167]

365. Chen L, Lu H, Wang J, Sarkar R, Yang X, Wang H, High KA, Xiao W. Enhanced factor VIII heavy chain for gene therapy of hemophilia A. Mol Ther. 2009; 17(3):417-24. [PubMed: 19127250]

366. Roth SD, Schuttrumpf J, Milanov P, Abriss D, Ungerer C, Quade-Lyssy P, Simpson JC, Pepperkok R, Seifried E, Tonn T. Chemical chaperones improve protein secretion and rescue mutant factor VIII in mice with hemophilia A. PLoS One. 2012; 7(9):e44505. [PubMed: 22973456]

367. Margaritis P, Arruda VR, Aljamali M, Camire RM, Schlachterman A, High KA. Novel therapeutic approach for hemophilia using gene delivery of an engineered secreted activated Factor VII. J Clin Invest. 2004; 113(7):1025-31. [PubMed: 15057309]

368. Ohmori T, Ishiwata A, Kashiwakura Y, Madoiwa S, Mitomo K, Suzuki H, Hasegawa M, Mimuro J, Sakata Y. Phenotypic correction of hemophilia A by ectopic expression of activated factor VII in platelets. Mol Ther. 2008; 16(8):1359-65. [PubMed: 18523449]

369. Kitazawa T, Igawa T, Sampei Z, Muto A, Kojima T, Soeda T, Yoshihashi K, Okuyama-Nishida Y, Saito H, Tsunoda H, Suzuki T, Adachi H, Miyazaki T, Ishii S, Kamata-Sakurai M, Iida T, Harada A, Esaki K, Funaki M, Moriyama C, Tanaka E, Kikuchi Y, Wakabayashi T, Wada M, Goto M, Toyoda T, Ueyama A, Suzuki S, Haraya K, Tachibana T, Kawabe Y, Shima M, Yoshioka A, Hattori K. A bispecific antibody to factors IXa and X restores factor VIII hemostatic activity in a hemophilia A model. Nat Med. 2012; 18(10):1570-4. [PubMed: 23023498]

370. Milanov P, Ivanciu L, Abriss D, Quade-Lyssy P, Miesbach W, Alesci S, Tonn T, Grez M, Seifried E, Schuttrumpf J. Engineered factor IX variants bypass FVIII and correct hemophilia A phenotype in mice. Blood. 2012; 119(2):602-11. [PubMed: 22031860] 


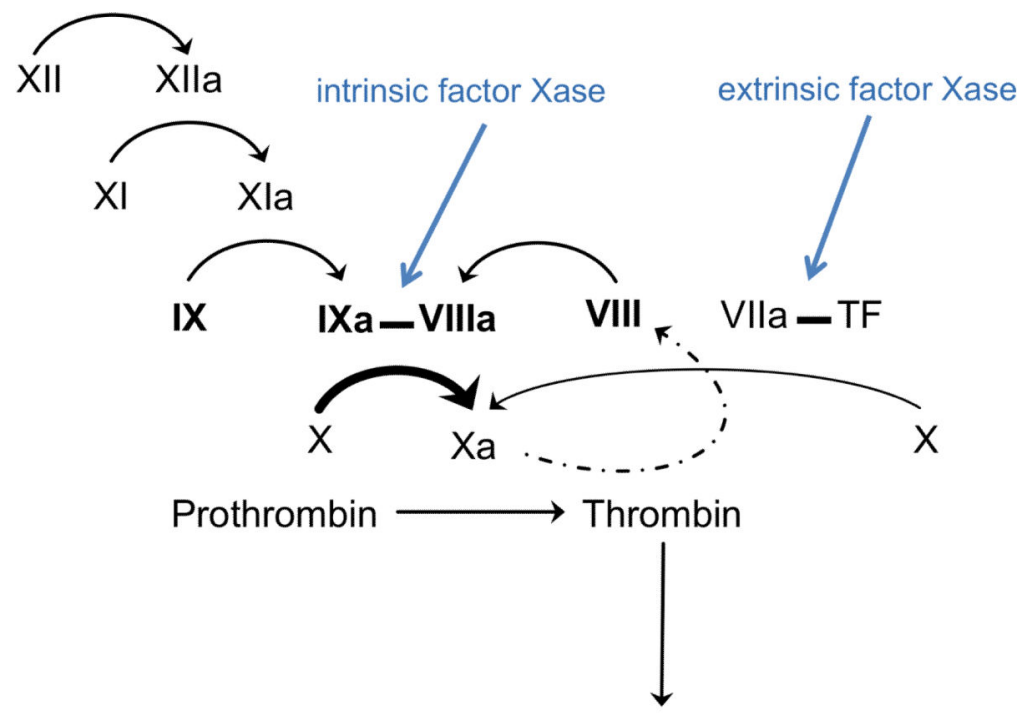

Fibrin clot

Figure 1.

Diagram of the coagulation cascade. Activation of F.XII by exposure to a damaged surface causes sequential activation of F.XI and F.IX. Similarly, activation of the extrinsic factor Xase (F.VIIa and tissue factor) leads to limited activation of F.X. This limited activation induces a feedback loop by activating F.VIII, which combines with F.IXa to form the intrinsic factor Xase. The intrinsic factor Xase then cleaves high levels of F.X, which induces the activation of prothrombin to thrombin, leading to formation of the cross-linked fibrin clot. 

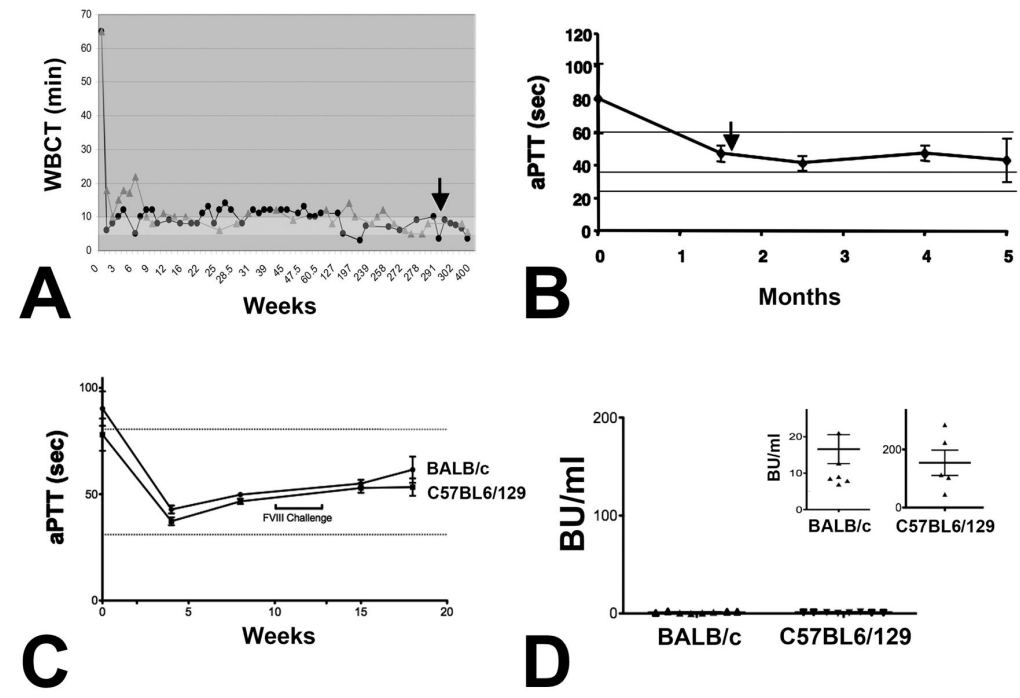

Figure 2.

Examples of sustained correction of hemophilia in animal models by hepatic AAV gene transfer. A. Sustained correction of the whole blood clotting time after hepatic AAV2-canine F.IX gene transfer in 2 hemophilia B dogs with F9 null mutation (Niemeyer et al., Blood 2009). B. Sustained correction of the activated partial thromboplastin time (aPTT) after hepatic AAV2-human F.IX gene transfer in hemophilia B mice $(n=4)$ with F9 gene deletion (Dobrzysnki et al., Proc Natl Acad Sci 2006). Arrows in A and B indicate challenge with/ immunization against FIX protein. C. Sustained correction of the aPTT after hepatic AAV8human FVIII gene transfer in hemophilia A mice (of 2 different strain backgrounds, $\mathrm{n}=8$ per strain) with F8 exon 16 gene deletion (Sack et al., PLoS One 2012). Mice were challenged with F. VIII protein injections at the indicated time interval. D. Lack of inhibitor formation in the hemophilia A mice treated with gene therapy and challenged with F.VIII protein (insert shows inhibitor titers in $\mathrm{BU} / \mathrm{ml}$ in response to $\mathrm{FVIII}$ in control mice that had not received gene transfer). 


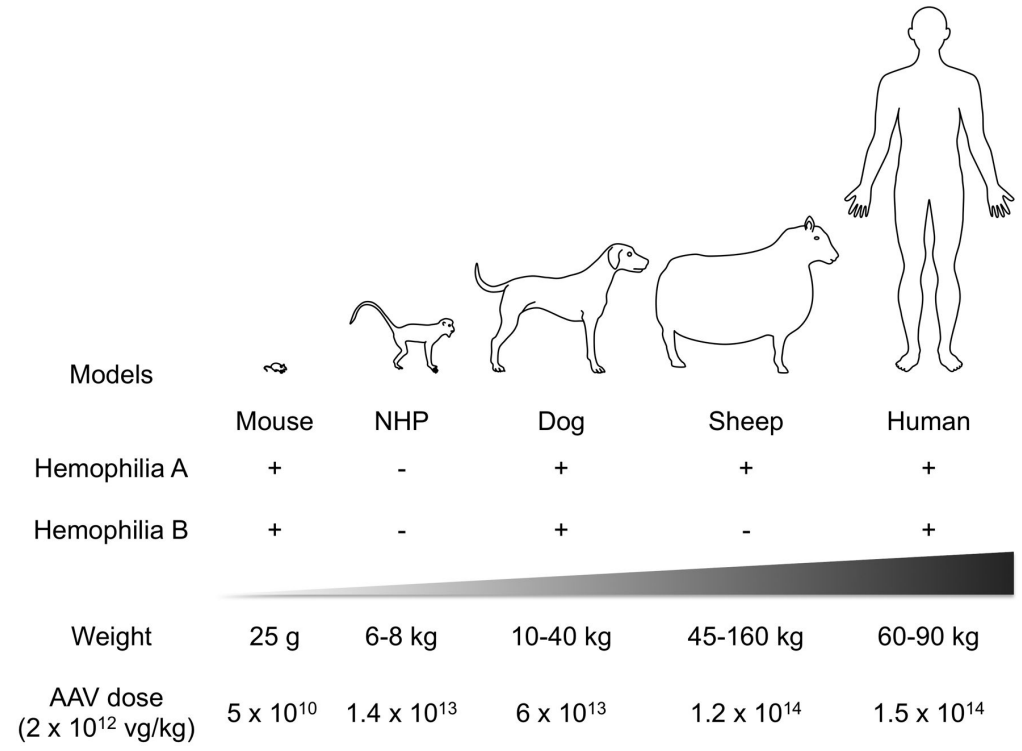

Figure 3.

Animal models of hemophilia. Preclinical studies of gene therapy for hemophilia have access to a variety of animal models. Models of both hemophilia A and B are available in mice, whereas dogs typically serve as the large animal model for both diseases. Although studies are performed in nonhuman primates, there are not hemophilic models of these animals available. Though not used very often, there is a model for hemophilia A in sheep. Finally, humans obviously suffer from both hemophilia A and B, and studies for both have been performed in clinical trials. An average range of weights for each animal is given below, and the average AAV vector dose that would be required for delivering $2 \times 10^{12}$ $\mathrm{vg} / \mathrm{kg}$ to each animal indicates how rapidly the vector titers required can increase with larger animals. 


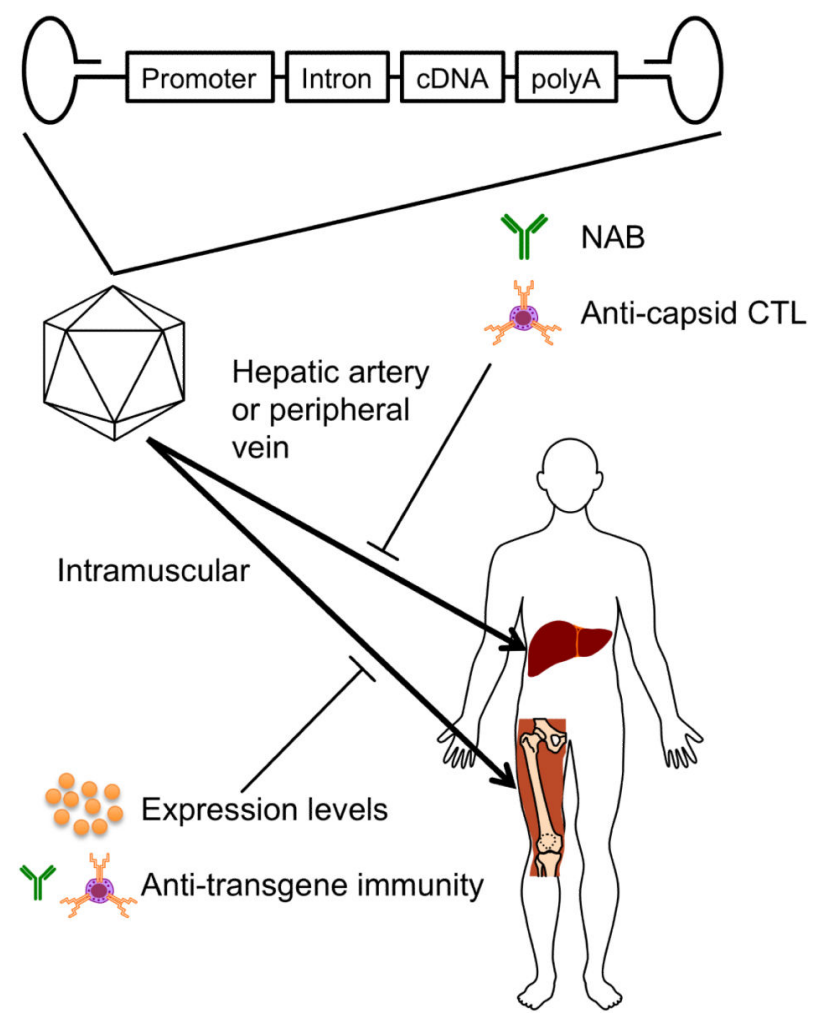

Figure 4.

AAV-mediated gene therapy for hemophilia B. A recombinant AAV vector is produced, whose genome includes the viral ITRs, as well as a promoter, intron, F.IX cDNA, and polyA tail. AAV has been used for intramuscular gene transfer, which was limited by nonphysiological expression levels in human trials, as well as anti-transgene immunity during some preclinical studies. Circulatory delivery of AAV for hepatic gene transfer, either via the hepatic artery or peripheral vein, has seen more success. However, this route can still be limited by anti-capsid NAB as well as reactivation of a memory $\mathrm{CD} 8^{+} \mathrm{T}$ cell response to the input viral capsid. 


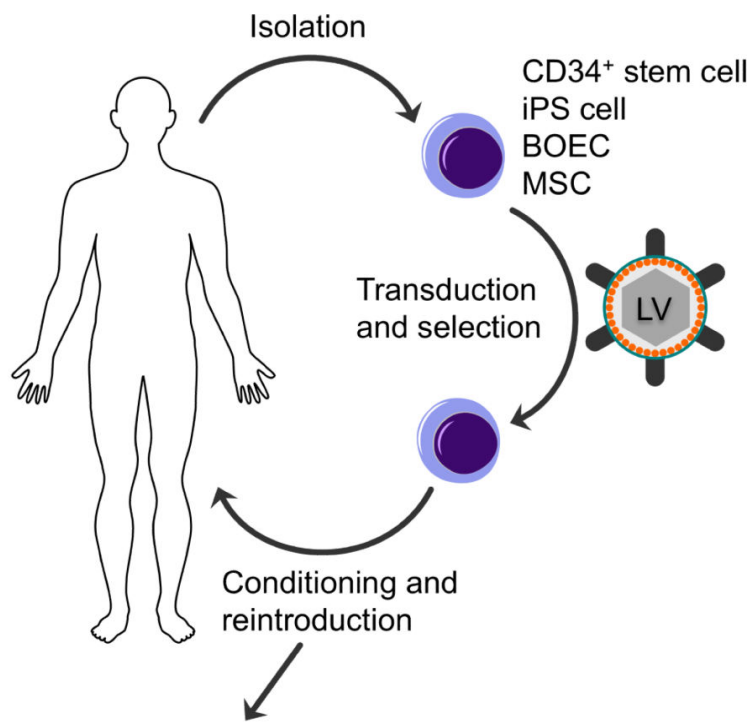

Differentiation and expression

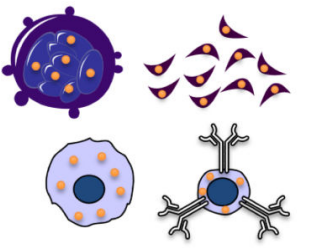

Figure 5.

Ex vivo gene transfer. Gene transfer to cells ex vivo is typically initiated by isolation of the relevant cell population (such as $\mathrm{CD} 34^{+} \mathrm{HSCs}$, iPS precursors, BOECs, MSCs, etc.) from the patient. Modification with LV or other integrating gene transfer system is performed, followed by a selection for transduced cells. If necessary, a conditioning regimen is given to the patient prior to reintroduction of the transduced autologous cells to ensure efficient engraftment. Finally, in the patient, these precursors are distributed and differentiated into the cells desired for expression, whether these are megakaryocytes, platelets, B cells, endothelial cells, MSCs, or some other cell type of interest. 
Table 1

Clinical trials of AAV-mediated gene therapy for hemophilia B

\begin{tabular}{|l|l|l|l|l|}
\hline Vector & Route of administration & Institute & Status & Reference/Identifier \\
\hline ssAAV2-CMV-hF.IX & Intramuscular & $\begin{array}{l}\text { Children's Hospital of Philadelphia/ } \\
\text { Stanford/Avigen }\end{array}$ & Complete & $(30)$ \\
\hline ssAAV2-hAAT-hF.IX & Hepatic artery & $\begin{array}{l}\text { Children's Hospital of Philadelphia / } \\
\text { Stanford/Avigen }\end{array}$ & Complete & $(52)$ \\
\hline scAAV8-LSP-hF.IXco & Peripheral vein & $\begin{array}{l}\text { St. Jude Children's Hospital/University } \\
\text { College London }\end{array}$ & Ongoing & $(53)$ \\
\hline ssAAV8-hAAT-hF.IXco & Peripheral vein & Children's Hospital of Philadelphia & Ongoing & NCT01620801 \\
\hline scAAV-TTR-hF.IXco-Padua & Peripheral vein & University of North Carolina & Ongoing & NCT01687608 \\
\hline
\end{tabular}

